\title{
Beyond Villages and Open Fields: The Origins and Development of a Historic Landscape Characterised by Dispersed Settlement in South-West England
}

\author{
By S. J. RIPPON, R. M. FYFE and A. G. BROWN
}

POLLEN EVIDENCE has, to date, made little contribution to our understanding of the origins and development of the medieval landscape. Compared to the prehistoric period, relatively few long palaeoenvironmental sequences provide a continuous record for the past two millennia, and those that have been analysed are mostly located in upland locations that lay beyond areas settled during this period. The nine sequences reported here from central Devon and the edges of Exmoor start to redress that imbalance. They suggest substantial clearance of woodland in lowland areas and the upland fringe by the Late Iron Age, and that the incorporation of this region into the Roman world had little impact on patterns of landscape exploitation. In a region that lay beyond the main area of Romanisation, it is not surprising that the $5_{\text {th }}$ century saw little discernible change in management of the landscape. These palaeoenvironmental sequences suggest that around the 7 th-8th centuries, however, there was a significant change in the patterns of land-use, which it is suggested relates to the introduction of a regionally distinctive system of agriculture known as 'convertible husbandry'. This may also have been the context for the creation of today's historic landscape of small hamlets and isolated farmsteads set within a near continuous fieldscape, replacing the late prehistoric/ Romano-British/post-Roman landscape of small, enclosed settlements with only very localised evidence for field systems. This transformation appears to be roughly contemporary with, or even earlier than, the creation of nucleated villages in the 'Central Province' of England, suggesting that the 'great replanning' was just one of several regionally distinctive trajectories of landscape change in the later Ist millennium A.D.

From the I6th century, topographical writers describe how the English landscape could be divided into three broad provinces, of which the 'champion' countryside of the Midlands, characterised by communally managed open fields surrounding nucleated villages, separated areas of 'woodland' landscape in south-eastern, northern and western England which were characterised by more enclosed field systems associated with dispersed patterns of settlement. ${ }^{1}$

${ }^{1}$ E.g. L. Toulmin Smith, The Itinerary of John Leland in or about the Years I 535-I 543, 2 (London, I 908), 47. 
The systematic mapping of Igth-century settlement character by Roberts and Wrathmell has defined these 'Central', 'South-eastern' and 'Northern and Western' Provinces in more detail, ${ }^{2}$ though archaeological and historical research to date has focused on the origins and development of villages and open fields in the 'Central Province', with a more or less implicit assumption that the remaining areas of England had failed to develop this 'classic' form of High-medieval landscape as they had low populations, were colonised late, or were simply peripheral to the centre of gravity of this late ist millennium landscape-reorganisation. ${ }^{3}$ So do areas beyond the 'Central Province' have an essentially late prehistoric/Romano-British form of landscape - a type of countryside that would have survived in the Midlands had it not been for the 'great replanning' that led to the creation of villages and open fields?

\section{DISTINGTIVE LANDSGAPE GHARAGTER IN THE SOUTH-WEST OF ENGLAND}

This study focuses on the origins of the historic landscape - the present pattern of fields, roads and settlements - in the South-West of England, and in particular a regionally distinctive system of rotational agriculture known as 'convertible husbandry' (discussed in detail below). Since at least the Iron Age, the South-West Peninsula had a landscape character somewhat distinct from the rest of Britain. In pre-Roman times the Blackdown and Quantock Hills (Fig. I), rising above the Axe Valley on the Devon-Dorset border and the Parrett Valley in the western part of the Somerset Levels, appear to have marked the western limit of the Durotriges, as reflected in the distribution of their pottery, coins and massively defended hillforts. ${ }^{4}$ This same Blackdowns-Quantocks line also marks the western limit of extensive Romanisation, with very few villas and no small towns or Romano-Celtic temples to the west of these hills (Fig. I). ${ }^{5}$ The Blackdowns-Quantocks line similarly represents the western limit for evidence of Early Anglo-Saxon settlement, acculturation and exchange networks as reflected in diagnostic structures (e.g. sunken feature buildings), burials and artefacts. ${ }^{6}$ In the High Middle Ages these same hills also marked the westernmost limit of parishes with a predominantly nucleated settlement pattern and associated regularly arranged open fields. ${ }^{7}$

So did the 'great replanning' that led to the 'village moment' in the Central Province simply not penetrate this far south-west? Having also escaped the

\footnotetext{
${ }^{2}$ B. K. Roberts and S. Wrathmell, An Atlas of Rural Settlement in England (London, 200o); idem, Region and Place: a Study of English Rural Settlement (London, 2002).

${ }^{3}$ E.g. G. Lewis, P. Mitchell-Fox and C. Dyer, Village, Hamlet and Field: Changing Medieval Settlements in Central England (Manchester, I 997), I 99-20 I; J. Thirsk, 'The common fields', Past E'Present, 29 ( I 964), 3-29; eadem, 'The origins of the common fields', Past E Present, 33 ( I 966), I 42-7; T. Williamson, Shaping Medieval Landscapes (Macclesfield, 2003), 5-6.

${ }^{4}$ B. Cunliffe, Iron Age Communities in Britain (London, I99 I, 3rd edn.), figs. 8. I and 8.3.

${ }^{5}$ B. Jones and D. Mattingly, An Atlas of Roman Britain (Oxford, I990); Ordnance Survey, Historical Map and Guide: Roman Britain, Fifth Edition (Southampton, $200 \mathrm{I}$ ).

${ }^{6}$ C. Arnold, An Archaeology of the Early Anglo-Saxon Kingdoms (London, I 988); B. Eagles, 'The archaeological evidence for settlement in the fifth to seventh centuries AD', I $3-32$ in M. Aston and C. Lewis (eds.), The Medieval Landscape of Wessex (Oxford, I 994); P. Rahtz, S. Hirst and S. M. Wright, Cannington Cemetery (London, 20oo).

7 S. Rippon, Historic Landscape Analysis: Deciphering the Countryside (York, 2004); idem, England's Landscapes, Volume 3: Landscapes of South-West England (London, 2006); Roberts and Wrathmell 2000, op. cit. in note 2, figs. I 7-I8.
} 


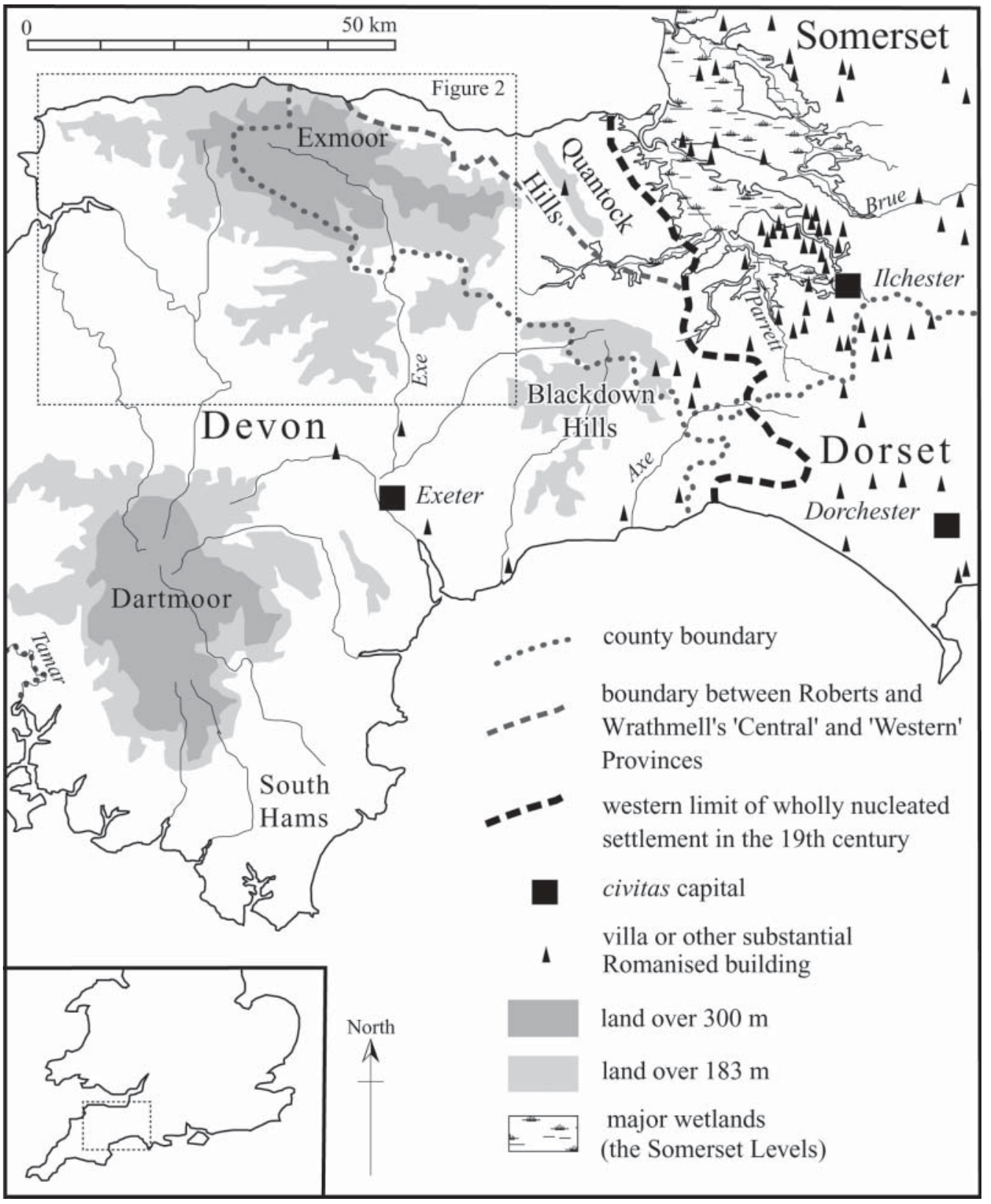

FIG. I

Location of the study area. The south-westerly limit of highly Romanised landscapes (as reflected in the distribution of villas, after Ordnance Survey 200 I, op. cit. in note 5), broadly corresponds to the south-westerly boundary of Roberts and Wrathmell's (2000, op. cit. in note 2) 'Central Province', which in turn reflects the distribution of medieval regularly arranged open-field systems (Rippon 2004, op. cit. in note 7 , figs. $27 \cdot 6-8)$. 
landscape transformations potentially brought about through extensive Romanisation, is it possible that the South-West's countryside is essentially of late prehistoric form? The answer appears to be no, both in terms of settlement form, distribution and their associated field systems. Survey and excavation in Devon has shown that the late prehistoric and Romano-British landscape was characterised by small, enclosed settlements containing one or more roundhouses, quite unlike the sprawling unenclosed hamlets and isolated farmsteads with rectangular longhouses that characterised the High- and Late-medieval countryside. ${ }^{8}$ Another major difference with the Medieval Period is that many of these late prehistoric and Romano-British enclosures which show up as cropmarks and earthworks, do not appear to be associated with field systems, ${ }^{9}$ while the small number of pre-medieval field systems that have been recorded bear no relationship to the historic landscape (being on a different orientation and not sharing any alignments). ${ }^{10}$ The increasing use of radiocarbon dating is starting to reveal the extent to which this late prehistoric/RomanoBritish tradition of enclosed settlements continued into the 6 th- 7 th centuries, with a significant move towards the recolonisation of hilltops also reflected in the occurrence of imported pottery in a number of reoccupied hillforts. The emergence of a series of coastal trading sites — both rocky islands and sheltered sandy beaches — that have produced large amounts of pottery imported from the Mediterranean can also be seen as a continuation of earlier trading traditions. ${ }^{11}$

${ }^{8}$ A. Fitzpatrick, C. Butterworth and J. Grove, Prehistoric $\&$ Roman Sites in East Devon: The Azo Honiton to Exeter Improvement DBFO Scheme, I 996-9 (Salisbury, I999); F. M. Griffith, 'Changing perceptions of the context of prehistoric Dartmoor', Proc. Devon Archaeol. Soc., 52 ( I 994), 85-99; K. Jarvis, 'The M5 Motorway and the Peamore/ Pocombe Link, Proc. Devon Archaeol. Soc., 34 (I976), 4 I-72; E. N. Mason Phillips, 'Excavations of a RomanoBritish site at Lower Well Farm, Stoke Gabriel, Devon', Proc. Devon Archaeol. Soc., 23 ( I 966), 2-62; H. Riley and R. Wilson-North, The Field Archaeology of Exmoor (London, 200 I), 65-75.

${ }^{9}$ F. M. Griffith, 'Roman military sites in Devon: some recent discoveries', Proc. Devon Archaeol. Soc., 42 ( I 984), I I-32; S. J. Reed and P. T. Manning, 'Archaeological recording of a hillslope enclosure at North Hill Cleave, Bittadon, North Devon', Proc. Devon Archaeol. Soc., 58 (2000), 20 I-I 4; R. J. Silvester, 'A hillslope enclosure at Collomoor, Bittadon', Proc. Devon Archaeol. Soc., 36 (I 978), 245-9; idem, 'Cropmark sites at North Tawton and Alverdiscott', Proc. Devon Archaeol. Soc., 36 (1978), 249-54; idem, 'An enclosure in Staverton Ford Plantation', Proc. Devon Archaeol. Soc., $3^{8}$ ( I980), I I 9-2 I; idem and C. J. Balkwill, 'Three hillslope enclosures in the Lyd Valley, West Devon', Proc. Devon Archaeol. Soc., 35 ( I 977), 8 I-4; S. J. Simpson, F. M. Griffith and N. Holbrook, 'The prehistoric, Roman and early post-Roman site at Hayes Farm, Clyst Honiton', Proc. Devon Archaeol. Soc., 47 ( I 989), I-28; M. Todd, 'A hillslope enclosure at Rudge, Morchard Bishop', Proc. Devon Archaeol. Soc., 56 ( 1998 ), I 33-52; J. Uglow, 'Three Romano-British sites in the Lower Exe Valley', Proc. Devon Archaeol. Soc., 58 (2000), $227-47$.

${ }^{10}$ Fitzpatrick et al., op. cit. in note 8; Jarvis, op. cit. in note 8; L. Gallant, N. Luxton and M. Collman, 'Ancient fields on the South Devon limestone plateau', Proc. Devon Archaeol. Soc., 43 ( I 995), 23-37; F. Griffith, Devon's Past (Exeter, I 988), 23; K. Jarvis and V. Maxfield, 'The excavation of a first century Roman farmstead and a late Neolithic settlement, Topsham, Devon', Proc. Devon Archaeol. Soc., 33 ( I 975), 209-65; E. N. M. Phillips, 'Excavation of a Romano-British site at Lower Well Farm, Stoke Gabriel, Devon', Proc. Devon Archaeol. Soc., 23 ( I 966), 2-62; G. F. Quinn, 'A new survey of the prehistoric field system on Kerswell Down and Whilborough Common', Proc. Devon Archaeol. Soc., 53 ( I 995), I 3 I-4; R. J. Silvester, 'The prehistoric open settlement at Dainton, south Devon', Proc. Devon. Archaeol. Soc., 38 (I980), I 7-48; S. Turner, "Coast and countryside in "Late Antique" southwest England, c. A.D. 400-6oo', 25-32 in R. Collins and J. Gerrard (eds.), Debating Late Antiquity (BAR Brit. Ser. 365, Oxford, 2004).

${ }^{11}$ B. Cunliffe, Mount Batten, Plymouth: A Prehistoric and Roman Port (Oxford, I 988); H. Gent and H. Quinnell, 'Excavations of a causewayed enclosure and hillfort on Raddon Hill, Stockleigh Pomeroy', Proc. Devon Archaeol. Soc., 57 ( I 999), I-76; idem, 'Salvage recording on the Neolithic site at Haldon Belvedere', Proc. Devon Archaeol. Soc., 57 (I999), 77-I04; F. M. Griffith and S. J. Reed, 'Rescue recording at Bantham Ham, South Devon, in i 997', Proc. Devon Archaeol. Soc., 56 ( г 998), г o9-3 I; H. Quinnell, Excavations at Trethurgy Round, St. Austell (Truro, 2004); Simpson et al., op. cit. in note 9; Turner, op. cit. in note io; idem, 'Imported and local pottery from Mothecombe: some new finds amongst old material in Totnes Museum', Proc. Devon Archaeol. Soc., 62 (2004), I 7 I -6; P. J. Weddell, 'The excavation of a post-Roman cemetery near Kenn, South Devon', Proc. Devon Archaeol. Soc., 56 (2000), 93-I26. 
Sometime around the late 6 th -7 th centuries, both ceramic and radiocarbon dating suggest that this landscape of hilltop settlements, coastal trading places and small enclosed farmsteads within what appears to have been a largely open countryside, was abandoned. The historic landscape of today is quite unrelated to what preceded it, both in the form (unenclosed farmsteads and small hamlets) and physical location of settlements. Around Exmoor, for example, out of dozens of late prehistoric/Romano-British enclosures, the two examples that lie close to High-medieval settlements - Bagley and Sweetworthy in Luccombe - appear to be unique. Even the character of the houses changed. The dominant form of medieval dwellings appears to have been the tripartite longhouse, which can certainly be dated to the I oth-I I th century at Mawgan Porth. These stand in sharp contrast to the unicellular oval/sub-oval huts of the RomanoBritish and Early Medieval Period. ${ }^{12}$ Dating the origins of this historic landscape is difficult, however, as rural settlements have failed to produce pottery from before the I 2 th century, though many essential features of the High-medieval countryside were clearly in existence by the Ioth-I Ith centuries when they are described in charter boundary clauses and the Domesday survey. ${ }^{13}$ The historic landscape of today appears, therefore, to have emerged sometime between the 6 th -7 th and the Ioth-I Ith centuries following a significant episode of discontinuity, or at least dislocation, in the physical fabric of the countryside. ${ }^{14}$

In such an archaeologically and historically 'dark age', palaeoenvironmental analysis has enormous potential for shedding new light on changing patterns of landscape exploitation throughout Britain. Compared to the prehistoric period, though, there has been disappointingly little work on sequences that cover the Romano-British and Medieval Periods despite their ability to supply a continuous, geographically specific and potentially high resolution record of land-use change. ${ }^{15}$ Work carried out has generally been on blanket peats from the highest uplands, beyond areas settled at that time, and so will at best provide only a highly generalised regional picture of land-use change. Where sequences exist from lowland areas, they are usually from equally untypical locations, notably extensive wetlands such as the Somerset Levels. In contrast, the work reported here has been based on a series of non-typical pollen sites — small valley and spring mires — which lay within the lowlands and upland margins of Mid- and northern Devon that were extensively settled

12 R. Bruce-Mitford, Mawgan Porth: A Settlement of the Late Saxon Period on the North Cornish Coast. Excavations 194952, 1954 and 1974 (London, I997); A. Preston-Jones and P. Rose, 'Medieval Cornwall', Cornish Archaeol., 25 ( I 986), I 35-85; Quinnell, op. cit. in note I I; Riley and Wilson-North, op. cit. in note 8, 73-5.

${ }^{13}$ H. C. Darby, 'The south-western counties', 348-92 in H. C. Darby and R. Welldon Finn (eds.), The Domesday Geography of South-West England (Cambridge, I967); D. Hooke, The Pre-Conquest Charter-Bounds of Devon and Cornwall (Woodbridge, I994).

${ }_{14}$ Preston-Jones and Rose, op. cit. in note i 2; P. Rose and A. Preston Jones, 'Changes in the Cornish countryside AD 400-I I Oo', figs. 3. I-3.2 in D. Hooke and S. Burnell (eds), Landscape and Settlement in Britain A.D. $400-1066$ (Exeter, I 995); S. Turner, 'Making a Christian landscape: early medieval Cornwall', i 76-8 in M. Carver (ed.), The Cross Goes North: Processes of Conversion in Northern Europe, A.D. 300-I 300 (Woodbridge, 2003).

${ }^{15}$ P. Dark, The Environment of Britain in the First Millennium A.D. (London, 200o); R. Tipping, 'Climatic variability and 'marginal' settlement in upland British landscapes: a re-evaluation', Landscapes, 3(ii) (2002), ı-29. 
during the Romano-British and Medieval Periods. These new pollen sequences, alongside an analysis of documentary evidence and the physical fabric of the historic landscape itself, are used to examine continuity and changes in patterns of land-use during the historic period, and to assess when the present landscape is likely to have come into being.

\section{THE POLLEN SITES}

This project sought potential sites for palynological investigation that lay within or very close to those areas of the landscape that were settled during the Romano-British and Medieval Periods. A total of nine sites were examined in a broad transect running from lowland Mid-Devon in the Rackenford area (c. $220 \mathrm{~m} \mathrm{O.D.)} \mathrm{through} \mathrm{to} \mathrm{the} \mathrm{upland} \mathrm{fringes} \mathrm{of} \mathrm{Exmoor} \mathrm{around} \mathrm{Molland}$ Common (c. $290 \mathrm{~m}$ ) and Parracombe (c. $340 \mathrm{~m}$ O.D.) in northern Devon (Figs. 2-4). In contrast to the earlier sequences recovered from the high upland blanket bogs of Exmoor, that could only ever give a very broad regional picture from an area in the order of several hundred square kilometres (Figs. 2-3: Codsend Moor, Hoar Moor and The Chains), ${ }^{16}$ the peat bogs used here were small in size (c. $30 \mathrm{~m}$ across). These give a relatively local catchment of just several square kilometres, though we selected several sites in close proximity for each study area to ensure that a typical picture emerged. Unlike raised bogs that are purely rainwater-fed and whose vegetation growth will be climatically driven, these small valley mires are supplied by ground water and overland flow so will not directly reflect climatic change. The stratigraphy within each of the mires also shows that they have never been drained, and so any changes in the pollen related to changing agricultural practices will reflect the management of the adjacent dryland areas rather than the mires themselves. The results of these new sequences can also be compared with previous work in the upland fringes of Exmoor (Moles Chamber), ${ }^{17}$ and the very limited and often poorly dated work in lowland Devon (Fig. 3: Bow in Mid-Devon, ${ }^{18}$ the Exe Bridges near Exeter, ${ }^{19}$ and Aller Farm in Stockland, ${ }^{20}$ in eastern Devon).

We examined and sampled the pollen sites using a $50 \mathrm{~mm}$-wide, Russian-style corer, with pollen samples taken at $40 \mathrm{~mm}$ intervals using $5 \mathrm{~mm}$

${ }^{16}$ P. D. Francis and D. S. Slater, 'A record of vegetational and land use change from upland peat deposits on Exmoor, Part 2: Hoar Moor', Proc. Somerset Archaeol. Nat. Hist. Soc., I 34 ( I 990), I-26; idem, 'A record of vegetational and land use change from upland peat deposits on Exmoor, Part 3: Codsend Moors', Proc. Somerset Archaeol. Nat. Hist. Soc., I 36 ( I 992), 9-28; P. D. Moore, D. L. Merryfield and M. D. R. Price, 'The vegetation and development of blanket mires', 203-35 in P. D. Moore (ed.), European Mires (London, I 984).

${ }^{17}$ R. M. Fyfe, Palaeochannels of the Exe Catchment: Their Age and an Assessment of Their Archaeological and Palaeoenvironmental Potential (unpubl. Ph.D. thesis, University of Exeter, 2000).

${ }^{18}$ C. J. Caseldine, B. J. Coles, F. M. Griffith and J. M. Hatton, 'Conservation or change? Human influence on the mid-Devon landscape', 6o-9 in R. A. Nicholson and T. P. O'Connor (eds.), People as Agents of Environmental Change (Oxford, 2000).

${ }^{19}$ C. Caseldine, S. Juggins and V. Straker, 'Preliminary palaeoenvironmental analyses of floodplain deposits from a section near the river Exe in Exeter, Devon', I 45-62 in P. Murphy and C. French (eds.), The Exploitation of Wetlands (Oxford, I 988 ).

${ }^{20} \mathrm{~J}$. M. Hatton and C. J. Caseldine, 'Vegetation change and land use history during the first millennium AD at Aller Farm, East Devon as indicated by pollen analysis', Proc. Devon Archaeol. Soc., 49 ( I99 I), io7-i 4. 


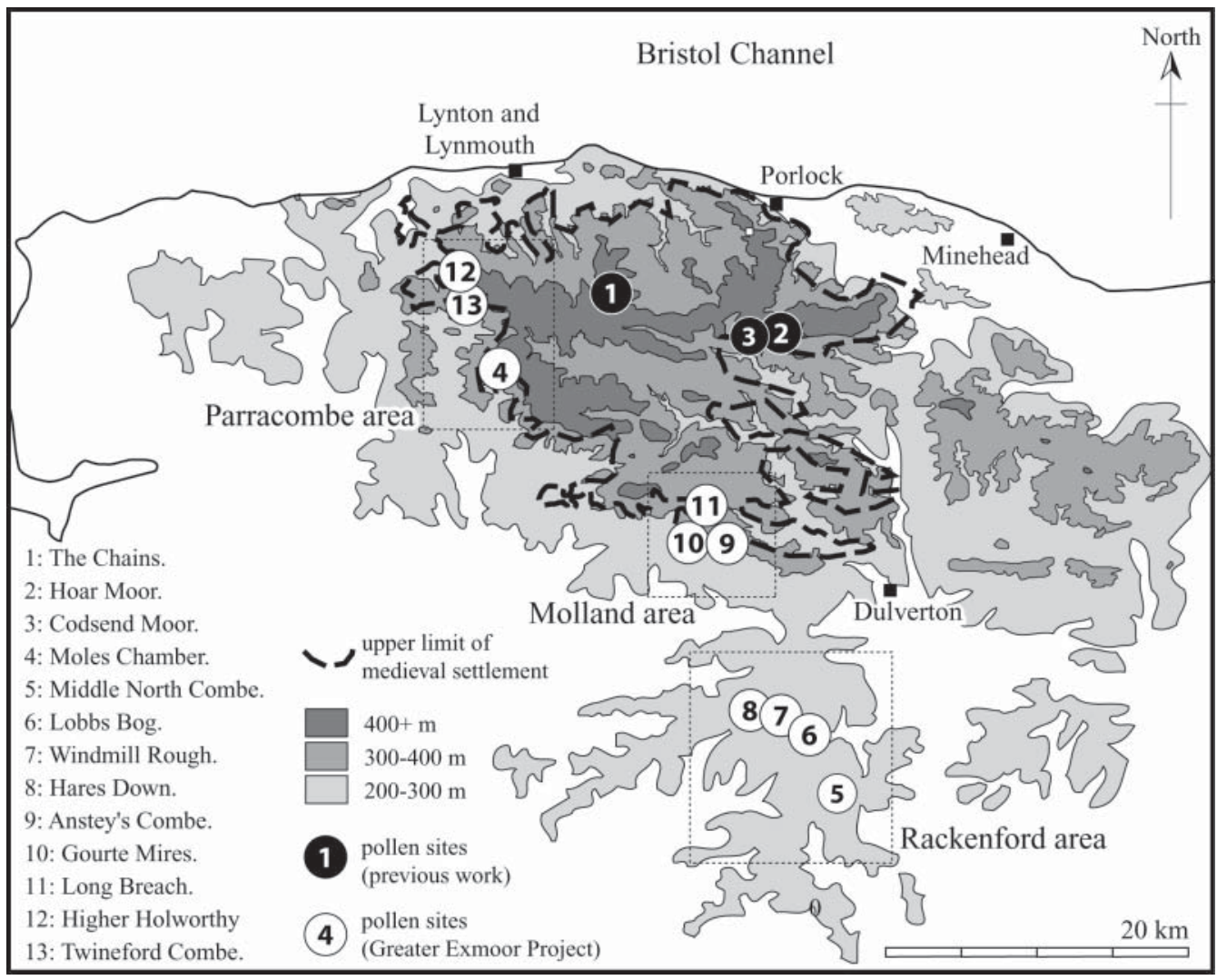

FIG. 2

Location of the pollen sites around Rackenford in Mid-Devon, Molland Common on the southern fringes of Exmoor and Parracombe in the western fringes of Exmoor. The previous pollen sites on Exmoor are mostly found on the blanket peats of the higher uplands (Codsend Moor, Hoar Moor and The Chains).

The inset boxes are shown in more detail in Figure 4 .

slices of peat. Pollen preparation followed standard procedures, ${ }^{21}$ and we identified pollen and spores using the standard keys in Moore et al., ${ }^{22}$ Andrew, ${ }^{23}$ and the University of Exeter reference collection, to a minimum sum of 500 land pollen grains. The data is presented as a percentage of the total land pollen count for each level. Pollen nomenclature follows Bennett, ${ }^{24}$ and the differentiation of Poaceae and cereal-types follows Andersen. ${ }^{25}$ Multiple samples were taken from each sequence for AMS dating using samples of peat $20 \mathrm{~mm}$ thick

${ }^{21}$ K. Faegri, P. E. Kaland and K. Krzywinski, Textbook of Pollen Analysis (Chichester, I989, 4th edn.).

22 P. D. Moore, J. A. Webb and M. E. Collinson, Pollen Analysis (Blackwell, i 99 I).

${ }^{23}$ R. Andrew, A Practical Pollen Guide to the British Flora (Quaternary Research Association Technical Guide no. I, Cambridge, I984).

${ }^{24}$ K. D. Bennett, Annotated Catalogue of Pollen and Pteridophyte Spore Types (unpubl. rep., Department of Plant Sciences, University of Cambridge, I 994).

${ }^{25}$ S. T. Andersen, 'Identification of wild grass and cereal pollen', Danmarks Geologiske Undersøgelse Arbog (I 978), $69-92$. 


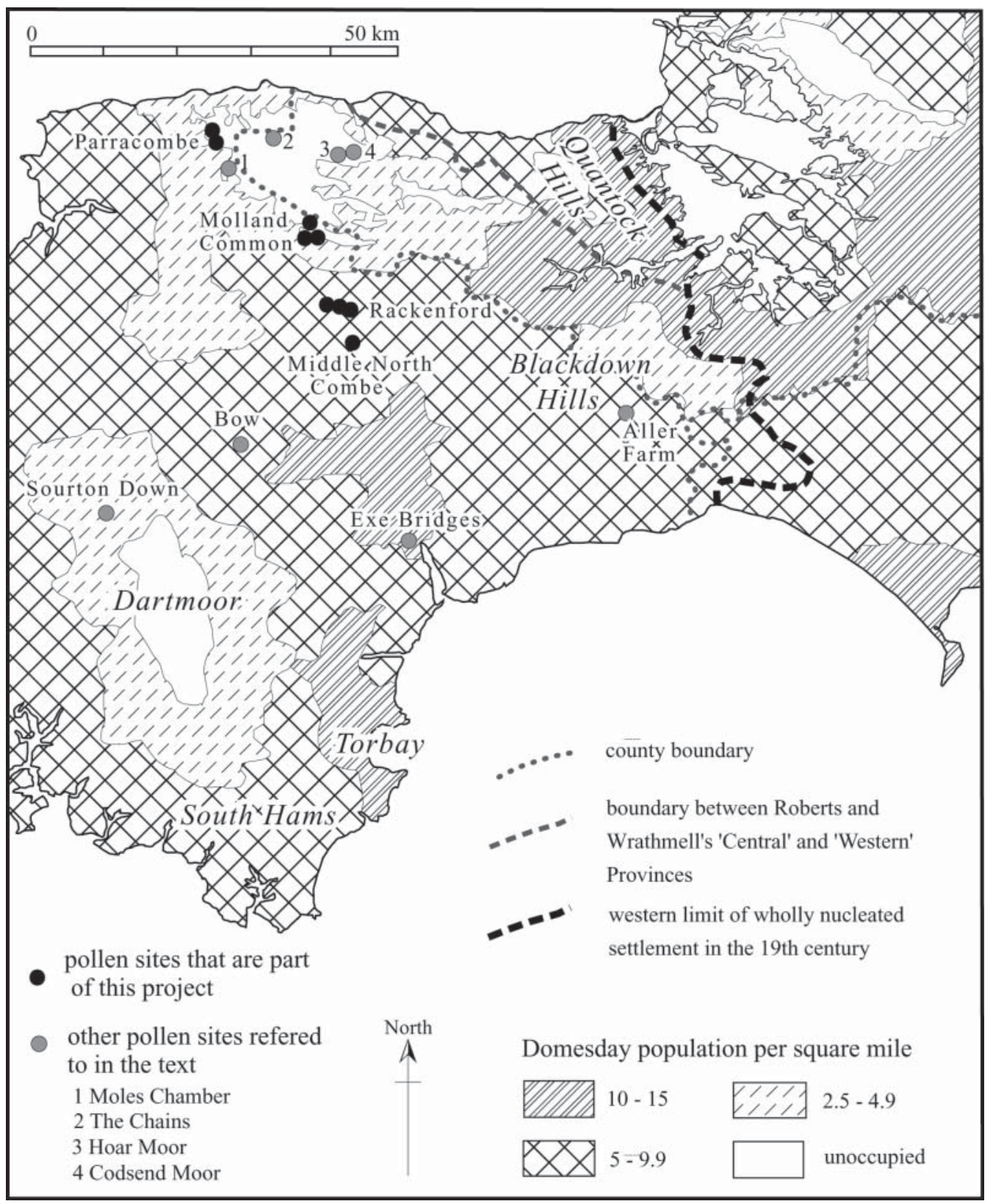

FIG. 3

Distribution of Domesday population in the South-West (after Darby and Welldon Finn, op. cit. in note I3, fig. 84), and the westerly limit of medieval landscapes characterised by nucleated villages and regularly arranged open fields (sources as Fig. I). 


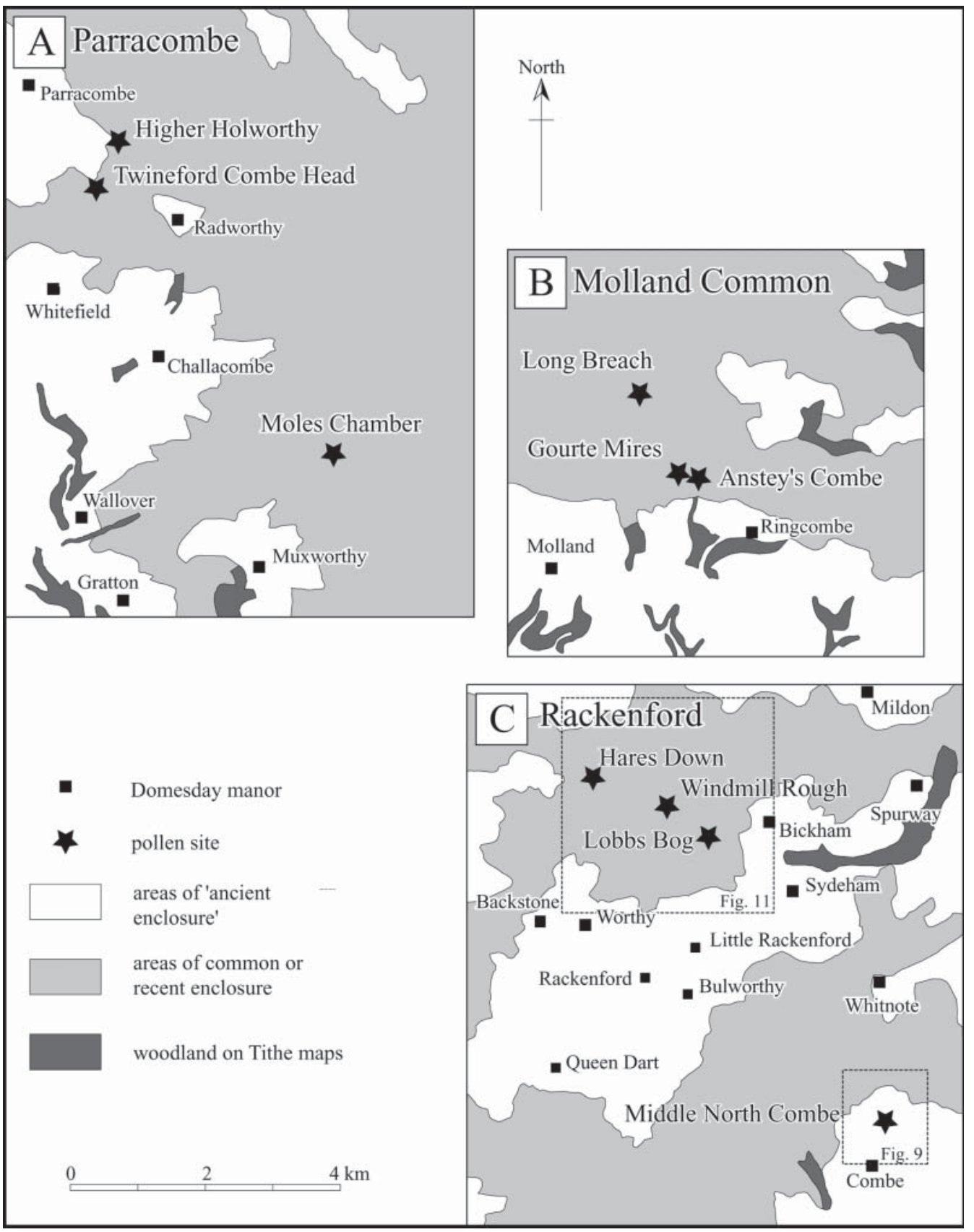

FIG. 4

Location of the pollen sites around Rackenford (Middle North Combe, Lobbs Bog, Windmill Rough and Hares Down), Molland Common (Anstey's Combe, Gourte Mires and Long Breach) and Parracombe (Higher Holworthy and Twineford Combe Head), in the context of Domesday manors and areas of ancient and recent enclosure (the latter being Parliamentary Enclosure or field systems of a similar 
submitted to the Radiocarbon facility at Waikato, New Zealand (with a single sample submitted later to the facility at BETA Radiocarbon, Miami, USA), and are calibrated using the age ranges at two sigma using the Calib 4.3 program. $^{26}$ Nine pollen diagrams and the accompanying reports could not be published in a single paper, so those for the Rackenford and Molland areas, which cover the prehistoric, Romano-British and historic periods, have been published elsewhere along with a general discussion of the prehistoric/Romano-British sections of the sequences. ${ }^{27}$ This paper presents the full publication of the wholly medieval sequences from Parracombe and a detailed discussion of the historic period for all the nine sites.

\section{RAGKENFORD AREA}

Four of the pollen sites lie on the clays, shales and sandstones of the Mid-Devon Culm Measures around Rackenford (Figs. ${ }_{4} \mathrm{C}$ and 8-I I). This is a landscape of gently undulating hills around 200 to $250 \mathrm{~m}$ O.D., occasionally dissected by steeply sided valleys whose sides are cloaked in woodland. The soils are slowly permeable, seasonally waterlogged, fine-grained loams with greater waterlogging on the higher interfluvial areas but better drainage in the broader valleys. ${ }^{28}$ In the Domesday Survey the region supported c. 2 plough-teams per square mile $[2.6 \mathrm{sq} \mathrm{km}]$ and a population of c. 6.5 tenants per square mile (Fig. 3). Both figures are about average for Devon and higher than parts of northern and western Devon that had I.6-r.8 plough-teams and under 5 tenants per square mile. Although not the agricultural heartland of Devon, this area was far from a 'marginal' region.

The historic landscape of this area (both today and as mapped in the igthcentury Tithe surveys) is characterised by a dispersed settlement pattern: numerous isolated farmsteads are typically set back from the through roads and accessed down narrow lanes; and a handful of small hamlets, mostly located around road junctions and the parish churches (e.g. Templeton, Rackenford and Knowstone). The landholdings associated with these igth-century farmsteads were compact with no evidence for the interspersed tenements seen in some parts of the South-West and that are suggestive of former small-scale open fields (see below). The through roads are sinuous and fairly narrow, though as they approach the higher interfluvial areas they have increasing amounts of

${ }^{26}$ M. Stuiver and P. J. Reimer, 'Extended ${ }_{4}$ C database and a revised CALIB radiocarbon calibration program', Radiocarbon, 35 (I 993), 2 I 5-30.

${ }^{27}$ Rackenford area (Middle North Combe, Lobbs Bog, Windmill Rough and Hares Down sequences): R. M. Fyfe, A. G. Brown and S. J. Rippon, "Characterising the late prehistoric, "Romano-British" and medieval landscape, and dating the emergence of a regionally distinct agricultural system in South West Britain', $\mathcal{F}$. Archaeol. Sci., 3 I (2004), I699-I 7 I 4. Molland Common area (Long Breach, Gourte Mires and Anstey's Combe sequences): idem, 'Mid to Late-Holocene vegetation history of Greater Exmoor, UK: estimating the spatial extent of human-induced vegetation change', Vegetation Hist. Archaeobotany, I 2 (2003), 2 I 5-32. Discussion of the Romano-British period: R. M. Fyfe and S.J. Rippon, 'Alandscape in transition? Palaeoenvironmental evidence for the end of the "Romano-British" period in South West England', 33-42 in Collins and Gerrard, op. cit. in note io.

${ }^{28}$ D. Mackney, J. M. Hodgson, J. M. Hollis and S. J. Staines, Legend for the I:250,00o Soil Map of England and Wales, Sheet 5 (Harpenden, I983): soils of the Hallsworth 2, Onecote and Neath associations. 
roadside waste and eventually broaden to form funnel-shaped droveways that enter a series of small unenclosed commons. Within the enclosed landscape, the field systems comprise blocks of small, broadly rectangular closes (enclosed fields not part of an open field system) typically with slightly curving or sinuous boundaries, while on the higher interfluvial areas distinctive blocks of straightsided fields, often with 'Moor' and 'Down' place- and field-names, represent post-medieval enclosures from the commons. ${ }^{29}$

The site at Middle North Combe (SS 8839 I 592, 223 m O.D.) is a small spring mire, $\mathrm{I} .35 \mathrm{~m}$ deep, in a minor tributary of the River Dart in Templeton parish. The sequence covers the Late Bronze Age to the present day. This well-populated area has places mentioned in the Domesday Book, including Combe (which became the Knights Templar manor of Templeton). ${ }^{30}$ The sites at Lobbs Bog (SS 86 го 2026, 254 m O.D.) and Windmill Rough (SS 85462074 , $259 \mathrm{~m}$ O.D.) are both small valley mires, $2.0 \mathrm{~m}$ and $\mathrm{I} .6 \mathrm{~m}$ deep respectively, in adjacent valley heads of the Little Dart River on Rackenford Moor in Rackenford parish, c. $6 \mathrm{~km}$ north-west of Middle North Combe (Fig. ${ }_{4} \mathrm{C}$ ). The site at Hares Down (SS 847 I 2 I I 3, 242 m O.D.), a narrow valley mire some $\mathrm{I} .5 \mathrm{~m}$ deep, draining into the Sturcombe River on Knowstone Outer Moor in Knowstone parish, lies I $\mathrm{km}$ further to the north-west. The Windmill Rough sequence covers the Late Bronze Age to the present day, while those at Lobbs Bog and Hares Down extend from the Middle Iron Age to the present. All three sites lie on the fringes of an extensive interfluvial plateau currently occupied by the unenclosed rough pasture of Rackenford and Knowstone Outer Moors. They are surrounded by undulating hills and valleys supporting a historic landscape very similar to Middle North Combe and equally well-populated with places included in the Domesday Survey (including Bickham c. I $\mathrm{km}$ to the east, Little Rackenford c. I $\mathrm{km}$ to the south and Backstone c. I.5 km to the south-west). An extensive relict landscape on Rackenford and Knowstone Outer Moors shows that the historic landscape once covered these areas too, in what was part of the near continuous fieldscape of lowland Mid-Devon (Fig. Io).

\section{MOLLAND GOMMON}

Three of the pollen sites lie on the sandstones, siltstones and slates of the southern fringes of Exmoor (Fig. ${ }_{4} \mathrm{~B}$ ). This is a landscape of rolling hills and steep-sided wooded valleys on the heavily dissected edge of the Anstey Ridge. The soils are predominantly well-drained loams with small areas of slowly permeable subsoil and slight seasonal waterlogging, but loamy soils with a peaty surface horizon on the unenclosed uplands. ${ }^{31}$ The three pollen sites reported here lie between c. 280 and $340 \mathrm{~m}$ O.D. and are close to the 'high-water mark' of I Ith-century settlement and cultivation. Around Exmoor as a whole Domesday manors are typically found up to 240 to $270 \mathrm{~m} \mathrm{O.D.} \mathrm{(e.g.}$

${ }^{29}$ Rippon 2004, op. cit. in note 7, fig. I 9; see also H. P. R. Finberg, West-Country Historical Studies (Newton Abbot, I 969), I 29-5 I, for a discussion of the documentary evidence for open-field agriculture in Devon.

${ }^{30}$ J. E. B. Gover, A. Mawer and F. M. Stenton, The Place-Names of Devon, Part II (Cambridge, I 932), 394.

31 Mackney et al., op. cit. in note 28: soils of the Neath and Lydcott associations. 
Ringcombe), with some as high as $300 \mathrm{~m}$ O.D. (e.g. Badgworthy) and even $360 \mathrm{~m}$ at Stone (in Exford), Radworthy (in Challacombe: Fig. $4 \mathrm{~A}$ ) and Lank Combe (in Brendon). The area supported c. I.8 plough-teams and c. 4.9 tenants per square mile. The historic landscape is similar to the Rackenford area, being characterised by a handful of small hamlets, mostly located around road junctions and the parish churches (e.g. Molland, East and West Anstey), and numerous isolated farms spreading up the valley sides to c. $25^{\circ} \mathrm{m} \mathrm{O.D.} \mathrm{Once}$ again, the landholdings associated with these farmsteads as recorded in the Tithe surveys were compact, with no evidence for the interspersion of tenements that is suggestive of former open fields. The upper limit of the enclosed fieldscape currently lies at c. $275^{-325} \mathrm{~m}$ O.D., though the earthworks of extensive relict field systems and plough ridges on what is now unenclosed moorland show that the pollen sites used to lie within the enclosed fieldscape (Fig. I 2). ${ }^{32}$ The roads are narrow and sinuous, and curiously show little sign of opening into funnelshaped droveways as they approach the open moor to the north. Within the enclosed areas, the field systems comprise blocks of broadly rectangular closes, typically with slightly curving or sinuous boundaries.

Anstey's Combe (SS 8272 2968, 282 m O.D.) and Gourte Mires (SS 8247 2969, 29I m O.D.) are two spring-fed mires towards the heads of two steep-sided valleys feeding into the River Yeo on the southern flanks of Molland Common, in the parish of Molland on the southern fringes of Exmoor. The sequence at Gourte Mires starts in the Late Neolithic, although it is truncated by recent erosion such that the Post-medieval Period has been lost. The sequence at Anstey's Combe starts in the Late Iron Age/early Romano-British Period, and extends to the present day. Both lie in unenclosed rough pastures c. $300 \mathrm{~m}$ to the north of a substantial earthen bank that marks the upslope limit of the present enclosed landscape. Long Breach (SS 8I 86 3097, 34 I m O.D.) is a valley mire towards the head of a tributary of the Danes Brook on the northern side of Molland Common. The sequence starts in the Late Mesolithic and extends to the present day.

\section{PARRACOMBE}

The final two pollen sites lie in the north-western fringes of Exmoor. Higher Holworthy (SS 6883 4404, 323 m O.D.) and Twineford Head Combe (SS 6756 4290, $334 \mathrm{~m}$ O.D.) are two spring mires towards the heads of two steep-sided valleys feeding into the River Heddon in the parish of Parracombe on the northern flanks of Challacombe Common (Fig. 4A). The Higher Holworthy sequence starts around the early i $3^{\text {th }}$ century (Fig. 5), while that at Twineford starts around the I4th century (Fig. 6; see below). Both sites lie just beyond the upper limits of an enclosed landscape of medieval character (blocks of broadly rectangular closes, typically with slightly curving or sinuous boundaries as seen in the other study areas), and a settlement pattern that while dominated by the village of Parracombe (c. I.8 $\mathrm{km}$ to the north-west), is 
otherwise characterised by small hamlets and isolated farmsteads, such as the Domesday manor of Radworthy ( $2 \mathrm{~km}$ to the east), Holworthy (0.5 $\mathrm{km}$ to the west of Higher Holworthy, first documented in I 2 I 5) and Highley ( I km north of Twineford Head, first documented in I 330). ${ }^{33}$ As with Molland Common, this region supported c. I.8 plough-teams and c. 4.9 tenants per square mile in the Domesday Survey.

The radiocarbon dates from the Parracombe sites provide some problems and necessitate the use of time series, rather than simple linear interpolation between radiocarbon dates (Tab. I). Additional time controls are made possible by using the surface of the peat as the present, and the appearance of significant amounts of pine at approximately i 750. Coniferous trees were introduced to southern England throughout the Post-medieval Period, notably Norway spruce (from the mid-I6th century), European larch and Scots pine (both from the early to mid-I 7 th century). Although conifer plantations in the South-West started in the late i8th century and became common from the mid-igth century, ornamental planting of pine trees in gardens and around homesteads was common from the i8th century. ${ }^{34}$ When these additional controls are included, it is possible to use mathematical models (second and third order polynomials) to estimate peat growth at the Parracombe sites, and assign calibrated ages to each individual level. ${ }^{35}$ Based on these models, the Higher Holworthy sequence begins around cal. A.D. I 220 and the Twineford Combe Head sequence begins around cal. A.D. I 36o. The pollen diagrams for the two sites are in Figures $5^{-6}$, and the sequence interpreted in Tables $2-3$.

\section{BEFORE THE HISTORIG LANDSGAPE}

\section{THE LATE PREHISTORIG BAGKGROUND}

The majority of the sequences from the Greater Exmoor region go back at least as far as the Middle Iron Age (4th-Ist centuries B.G.; Fig. 7). Around Rackenford and Molland there was a predominantly open, pastoral landscape dominated by grassland and herbaceous species, with local alder woodland in some of the steeper-sided valleys; other woodland species, notably oak and hazel, along with heather, occur at relatively low levels. Although the landscape around the pollen sites was a largely pastoral one, this does not preclude some arable cultivation in nearby areas. Cereal pollen does not travel far as it is not released very easily from the ears, and the large grain size means that it is not

\footnotetext{
${ }^{33}$ Gover et al., op. cit. in note 30,67 .

${ }^{34}$ W. J. Bean, Trees and Shrubs Hardy in the British Isles (London, I 976), vol. II, 5 I 9, and vol. III, I 79 and 243; J. Billingsley, General View of the Agriculture of the County of Somerset (London, I 797), 228; J. Bond, Somerset Parks and Gardens: A Landscape History (Tiverton, I 998); N. D. G. James, A History of English Forestry (Oxford, I 98 I), I65; R. Miles, Forestry in the English Landscape (London, I967), 36, 44, 47-8; A. Mitchell, The Complete Guide to Trees of Britain and Northern Europe (Limpsfield, I 985), I 56, I 58, I66; C. S. Orwin and R. J. Sellick, The Reclamation of Exmoor Forest (Newton Abbot, I970), 43, 56, 94-7, I I I C. Vancouver, General View of the Agriculture of Devon (London, r 808), 263; R. Whitlock, Historic Forests of England (Bradford-on-Avon, I 979), 3 I, 66.

${ }_{35}$ Higher Holworthy: the pine rise occurs at $0.4 \mathrm{~m}$ and, omitting Wk-1 254 I at I.03-1.05 $\mathrm{m}, \mathrm{y}=$ $-0.0007 \times 3+0.1028 \times 2-9.2548 \mathrm{x}+2000(\mathrm{r} 2=\mathrm{I})$. Based on this, HH begins at around cal. A.D. I 220. Twineford Combe Head: the pine rise occurs at I. I m and omitting the 'modern' dates gives y $=-0.0$ I 25 x2 $0.8969 \mathrm{x}+2000(\mathrm{r} 2=\mathrm{I})$. Based on this, TCH begins at around cal. A.D. I360.
} 

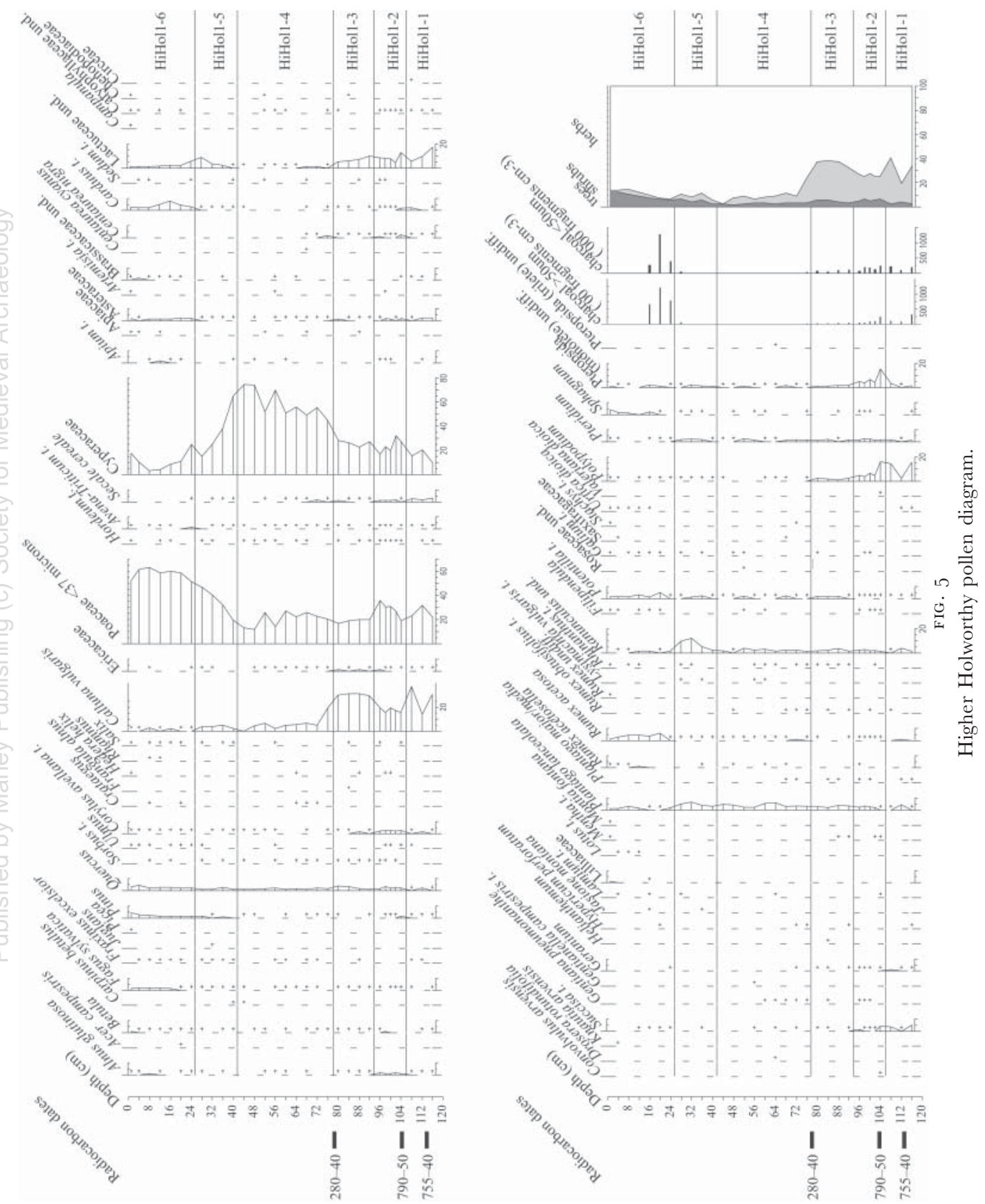

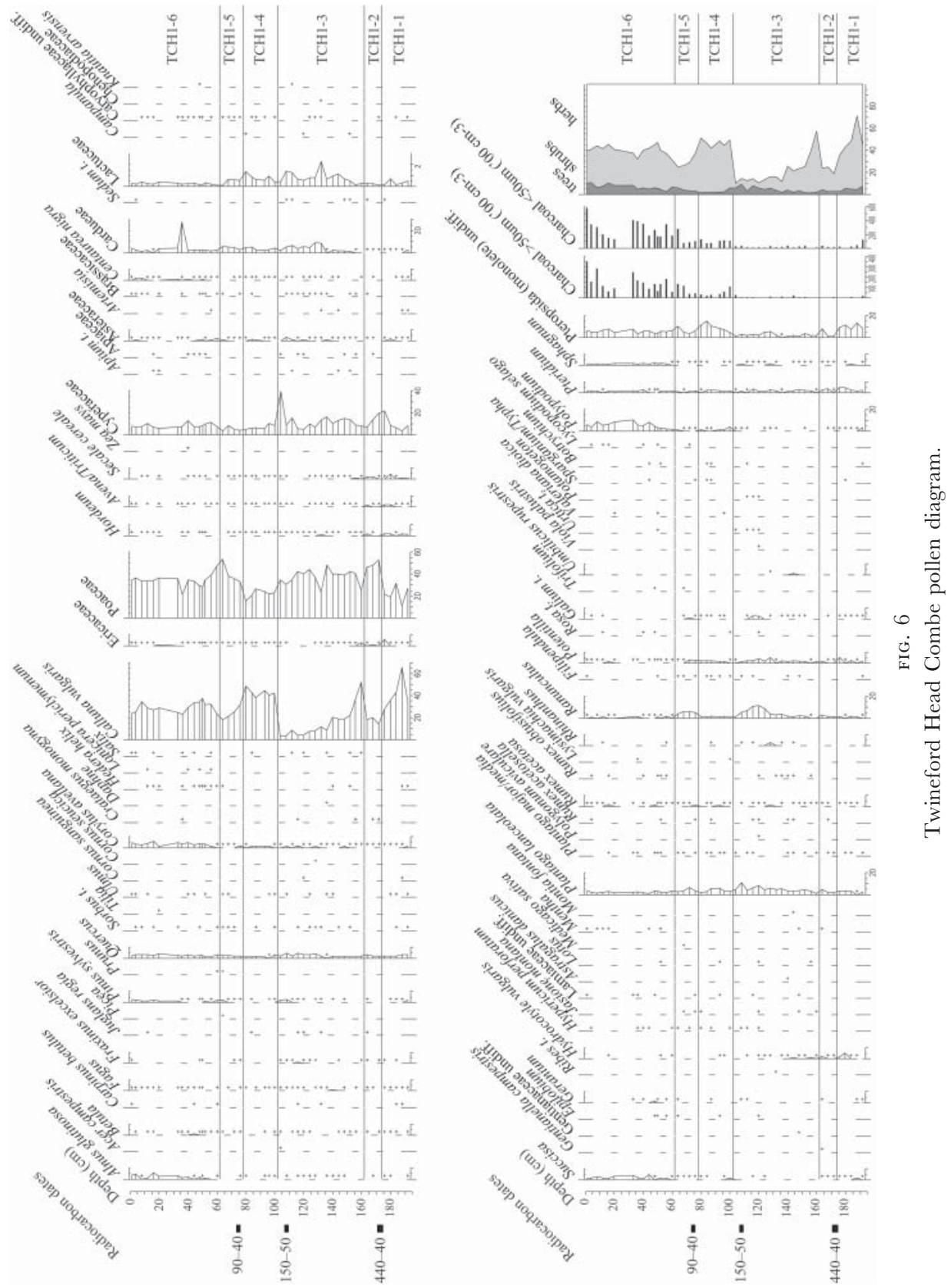
TABLE I

RADIOCARBON DATES FROM THE TWO POLLEN SEQUENCES FROM PARRACOMBE

\begin{tabular}{|c|c|c|c|c|c|}
\hline Lab code & Sample & Depth (m) & Date B.P. & $D_{13}$ & Calibrated range (2-sigma) \\
\hline \multicolumn{6}{|c|}{ Higher Holworthy } \\
\hline Wk- I 2540 & Hi-Hol I & I. I $3-$ I 5 & $755 \pm 3^{8}$ & $-26.0 \pm 0.2$ & cal. A.D. I $2 \mathrm{IO}^{-} \mathrm{I} 300$ \\
\hline Wk- I 254 I & $\mathrm{Hi}^{-\mathrm{Hol}_{2}}$ & I.03-5 & $786 \pm 47$ & $-25.7 \pm 0.2$ & cal. A.D. I I 60-I 300 \\
\hline Wk- I 2542 & $\mathrm{Hi}^{-\mathrm{Hol}_{3}}$ & $0.77-9$ & $282 \pm 43$ & $-26.9 \pm 0.2$ & cal. A.D. I $480-1670$ \\
\hline \multicolumn{6}{|c|}{ Twineford Head Combe } \\
\hline Wk- I 2543 & TCH I- I & I. $74-6$ & $44^{I} \pm 39$ & $-29.9 \pm 0.2$ & cal. A.D. I $400-1520$ \\
\hline Wk- I 2544 & $\mathrm{TCH}_{\mathrm{I}-2}$ & I.07-8 & I $53 \pm 4^{6}$ & $-26.8 \pm 0.2$ & Modern \\
\hline Wk- I 2545 & $\mathrm{TCH}_{\mathrm{I}-3}$ & $0.74^{-5}$ & $93 \pm 43$ & $-28.0 \pm 0.2$ & Modern \\
\hline
\end{tabular}

blown very far (in comparison to most trees, which produce large amounts of small, light pollen grains that are released from an elevated position). ${ }^{36}$ All that we can say from these sequences is that there was probably little or no arable cultivation within a kilometre or two of the pollen sites.

A number of the sequences show a marked phase of woodland clearance during the Middle-Late Iron Age, a phenomenon also seen on the higher slopes of Exmoor at the very end of the Iron Age/start of the Romano-British Period at Moles Chamber, The Chains and Hoar Moor. Anstey's Combe, in contrast, appears to have retained its local woodland throughout this period in what was a particularly steep-sided valley. Beyond these combes there is continuity in the predominantly pastoral land-use and very slight evidence for arable cultivation at a handful of sites (Middle North Combe, Anstey's Combe and Long Breach). The end of the Iron Age appears to have seen a shift to wetter heath vegetation around Molland Common, though a continuous record of microscopic charcoal suggests that burning continued to be an important means of managing the heathland. The shift to damper heath vegetation may reflect a climatic deterioration, or a change in landscape management with a clearer division between managed species-rich grassland and heathland left to develop or regenerate in the open areas beyond.

\section{GONTINUITY AGROSS THE ROMANO-BRITISH PERIOD}

From the very end of the Iron Age and throughout the Romano-British Period it is clear that pastoral activities in an open landscape dominated both the lowlands around Rackenford and the southern upland fringes of Exmoor. There are low, yet persistent, levels of cereals at a number of sites, with the best representation at the lowest-lying location, Middle North Combe, although the relatively low overall representation of cereal pollen suggests that cultivation

${ }^{36}$ I. Vuorela, 'The indication of farming in pollen diagrams from southern Finland', Acta Botanica Fennica, 87 (I970), I-40. 
TABLE 2

\section{DESGRIPTION AND INTERPRETATION OF POLLEN ZONES WITHIN THE HIGHER HOLWORTHY I SAMPLE CORE}

Zone HiHolı-ı. I. I8-i.o6 m. cal. A.D. i 220-1340. Poaceae-Calluna-Cyperaceae

Overwhelmingly dominated by herbaceous and dwarf shrub taxa, indicating a landscape cleared of almost all woodland. Calluna vulgaris at significant levels, indicating heather heath within the pollen catchment. The herbaceous taxa include cultivars (Secale cereale, traces of Avena/Triticum-type), ruderals indicative of cultivation (Asteraceae, Rumex acetosa) and pastoral indicators (Lactuceae, Plantago lanceolata, Geranium, Ranunculus acris-type). On-site vegetation is characterised by the high level of Cyperaceae, and species indicative of wet flushes (e.g. Succisa). Charcoal recorded in zone, possibly relating to management of open heath.

Zone HiHolı-2. I.o6-0.94 cm. cal. A.D. I340-I460. Poaceae-Calluna-Cyperaceae

Small increases in tree taxa (Alnus, Corylus avellana-type). Poaceae increase at expense of Calluna vulgaris, possibly indicating shift in character of upland heath. Cultivars continue to be recorded and little change in the herbaceous taxa.

Zone HiHolı-3. 0.94-0.78 m. cal. A.D. I460-i 570. Calluna-Cyperaceae-Poaceae

Calluna vulgaris expands at expense of Poaceae. Decline in tree taxa (Alnus, Corylus avellana-type) to trace levels. Decline in indicators of cultivation (Secale cereale, Asteaceae, Rumex acetosa) and some decline in certain pastoral indicators (e.g. Centaurea nigra). Reduction in large charcoal fragments.

Zone HiHolı-4. 0.78-0.42 m. cal. A.D. I 570-I 740. Cyperaceae-Poaceae

Quercus only tree taxa recorded above trace levels. Local wet-taxa dominate the assemblage (Cyperaceae), although indicators of cultivation and pastoral land-use continue to be recorded, at both trace levels (Secale cereale) and higher (e.g. Plantago lanceolata). Range of herbaceous taxa declines, possibly due to filtering effect of sedge-dominated local vegetation. No charcoal recorded throughout the zone.

Zone HiHolı-5• 0.42-0.26 m. cal. A.D. I 740-1820. Poaceae-Cyperaceae

Transitional zone where Poaceae increase to dominate assemblage at expense of local taxa (Cyperaceae). Heather heath remains poorly represented. Cultivars continue to be recorded at trace levels, indicating continued cultivation within the pollen catchment.

Zone HiHoli-6. 0.26-o m. cal. A.D. i 820-present. Poaceae

Dominated by pastoral indicators, although ruderal taxa continue to be recorded (Asteraceae, Rumex acetosa) and evidence for cultivars becomes sporadic. Significant increase in charcoal at the start of the zone, indicating significant burning within the local area (possibly relating to heathland management).

was not being extensively practised in the immediate proximity of the mires. Although the landscape was predominantly open, all the pollen sequences indicate some woodland, notably oak and hazel, which was presumably restricted to the steeper-sided valleys. There is little evidence in the pollen record for the management of woodland, although charcoal from two Romano-British iron-working sites on the fringes of Exmoor (at Brayford and 


\section{TABLE 3}

\section{DESGRIPTION AND INTERPRETATION OF POLLEN ZONES WITHIN THE TWINEFORD COMBE I SAMPLE CORE}

Zone TCHı-г. I.92-I.74 m. cal. A.D. I 360-I460. Calluna vulgaris-Poaceae

Dominated by herbaceous taxa and dwarf shrubs. Calluna vulgaris is dominant, indicating heather heath in the pollen catchment. Herbaceous taxa include cultivars (Avena/Triticum-type, Secale cereale), pastoral indicators (Poaceae, Plantago lanceolata, Potentilla-type) and on-site wetland taxa (Hydrocotyle vulgaris, Cyperaceae). Tree taxa are very poorly represented (only Quercus above trace levels), indicating a predominantly open landscape.

Zone TCHi-2. I.74-i.62 m. cal. A.D. I460-i 520. Poaceae-Calluna vulgaris

Calluna vulgaris decline and replaced by Poaceae, suggesting a shift from heather- to grass-dominated upland heath, possibly reflecting changes in the management of grazing. Little change in other taxa.

Zone TCHi-3. г.62-I.02 m. cal. A.D. I 520-I 780. Poaceae-Calluna vulgaris

Starts with an increase in Calluna vulgaris at the expense of Poaceae, though through the zone Poaceae become dominant. Cultivars (Secale cereale, Avena/Triticum-type) decline to trace levels. Pastoral indicators continue (Ranunculus acris-type, Potentilla-type, Lactuceae, Plantago lanceolata). Tree taxa continue to be poorly represented.

Zone TCHi-4. I.02-0.78 m. cal. A.D. I 780-1850. Calluna vulgaris-Poaceae

Sharp rise in Calluna vulgaris at start of zone and slight decline in Poaceae. Cultivars continue to be recorded in trace levels, tree taxa remain low and include Quercus and Corylus avellana-type at low levels. Charcoal levels rise for the first time in the diagram.

Zone TCHi-5. 0.78-0.62 m. cal. A.D. i 850-igoo. Poaceae-Calluna vulgaris

Transitional zone in which Calluna vulgaris steadily declines and Poaceae steadily rise. Possibly indicative of changes in management of upland grazing.

Zone TCHi-6. o.62-o m. cal. A.D. I9oo-present. Poaceae-Calluna vulgaris

Little change other than slight increase in tree taxa (Alnus glutinosa, Pinus sylvestris, Quercus, Corylus avellana-type). Cultivars recorded sporadically, and main taxa recorded (Poaceae and Calluna vulgaris), indicate the persistence of heather-heath and improved pastoral land.

Sherracombe) have suggested that some pollarding and coppicing of oak and hazel woodland may have occurred. ${ }^{37}$

Though we have to take great care converting radiocarbon dates to calendar years, a number of episodes showing an increasing intensity with which the landscape was exploited could date to the later Romano-British Period. Interpolating between radiocarbon dates, a decline in alder and expansion in grassland at Lobbs Bog may date to this period, ${ }^{38}$ while on the higher uplands of Exmoor a marked episode of woodland clearance and evidence for cereal

${ }^{37}$ R. Gale, Sherracombe Ford and Brayford, Exmoor, 2002: The Analysis of Charcoal from Romano-British Iron-working Sites - Interim Report (unpubl. rep., Exmoor Iron Project, University of Exeter, 2002).

${ }^{38}$ Interpolated date of c. I 700 B.P. 
cultivation at Codsend Moor and Hoar Moor is also potentially dated to around the 3 rd-4th centuries. ${ }^{39}$ Elsewhere, in the lowlands of eastern Devon there was a marked phase of woodland clearance in the valley at Aller Farm in Stockland and an increase in the indicators of pastoralism around the 3 rd century. ${ }^{40}$ This possible later Roman intensification in Devon parallels that seen to the east in Somerset and Dorset where the $3 \mathrm{rd}-4$ th centuries saw considerable agricultural wealth and innovation as reflected in wetland reclamation, investment in villas (also seen at Holcombe in east Devon) and urban prosperity. ${ }^{41}$

\section{THE ROMAN-MEDIEVAL TRANSITION}

The earlier work on 'traditional' pollen sites — the blanket bogs covering the higher uplands of Exmoor at Hoar Moor, The Chains and possibly Codsend Moor - suggests there was a decline in grassland, and increase in heather and possibly woodland, around the $5^{\text {th }}$ century, supporting the traditional view of woodland regeneration in the Early Medieval Period. ${ }^{42}$ The new sequences obtained from the lowlands and upland fringes present a very different picture. During the $4^{\text {th }}-6$ th centuries A.D. there is very little significant change in any of the pollen records suggesting continuity in an essentially pastoral landscape, with no evidence of woodland regeneration (Fig. 7). In this context, it could be inferred that there are unlikely to have been any major changes in the physical structure of the landscape (e.g. abandonment of field systems or desertion of settlement), the way in which it was managed or the tenurial structures within which it was exploited. Considering the very limited degree of Romanisation evident in the landscape of the South-West, outside of the immediate hinterland of the civitas capital Isca Dumnoniorum (Exeter), this should not be surprising; a rural population that had not become heavily engaged in the socio-economic systems of Roman Britain would be relatively unaffected by their decline.

\section{THE EMERGENGE OF THE HISTORIC LANDSGAPE}

CHANGES IN THE POLLEN REGORD

Around the 7th-8th centuries, the pollen sequences from around Rackenford in Mid-Devon show significant changes in the local vegetation (Fig. 7). At Middle North Combe (an interpolated date around I 350 B.P., c. A.D. 600-800), Lobbs Bog ( $240+50$ B.P., cal. A.D. 670-890) and Windmill Rough (shortly after $3_{380} \pm 5^{\circ}$ B.P., cal. A.D. 560-770), the change is characterised by

${ }^{39}$ Hoar Moor: $1760 \pm 80$ B.P., cal. A.D. 78-43 I: Francis and Slater i99o, op. cit. in note i6, I4; Codsend Moor: i66o \pm i 30 B.P., cal. A.D. I $26-640$ : ibid., I $2-$ I 4 ; idem, op. cit. in note i 6, r $992,23$.

${ }_{40}$ Aller Farm, Stockland: I $790 \pm 50$ B.P., cal. A.D. I $3^{2-323}$ : Hatton and Caseldine, op. cit. in note 20 , I I 2.

${ }^{41}$ R. Leech, 'The Roman interlude in the South West: The dynamics of economics and social change in the Romano-British south Somerset and north Dorset', 209-67 in D. Miles (ed.), The Romano-British Countryside (Oxford, I 982); S. Pollard, 'A Late Iron Age settlement and a Romano-British villa at Holcombe, near Uplyme, Devon', Proc. Devon Archaeol. Soc., 32 (I 974), 59-16ri; S. Rippon, The Transformation of Coastal Wetlands (London, 2000), I I $7-23$.

${ }^{42}$ Hoar Moor: interpolated date several centuries after i $760 \pm 80$ B.P., cal. A.D. 78-43 I, Francis and Slater I990, op. cit. in note I6, I4; The Chains: I500 \pm 6o B.P., cal. A.D. I 20-66o, Moore et al., op. cit. in note I6, tab. 2. 

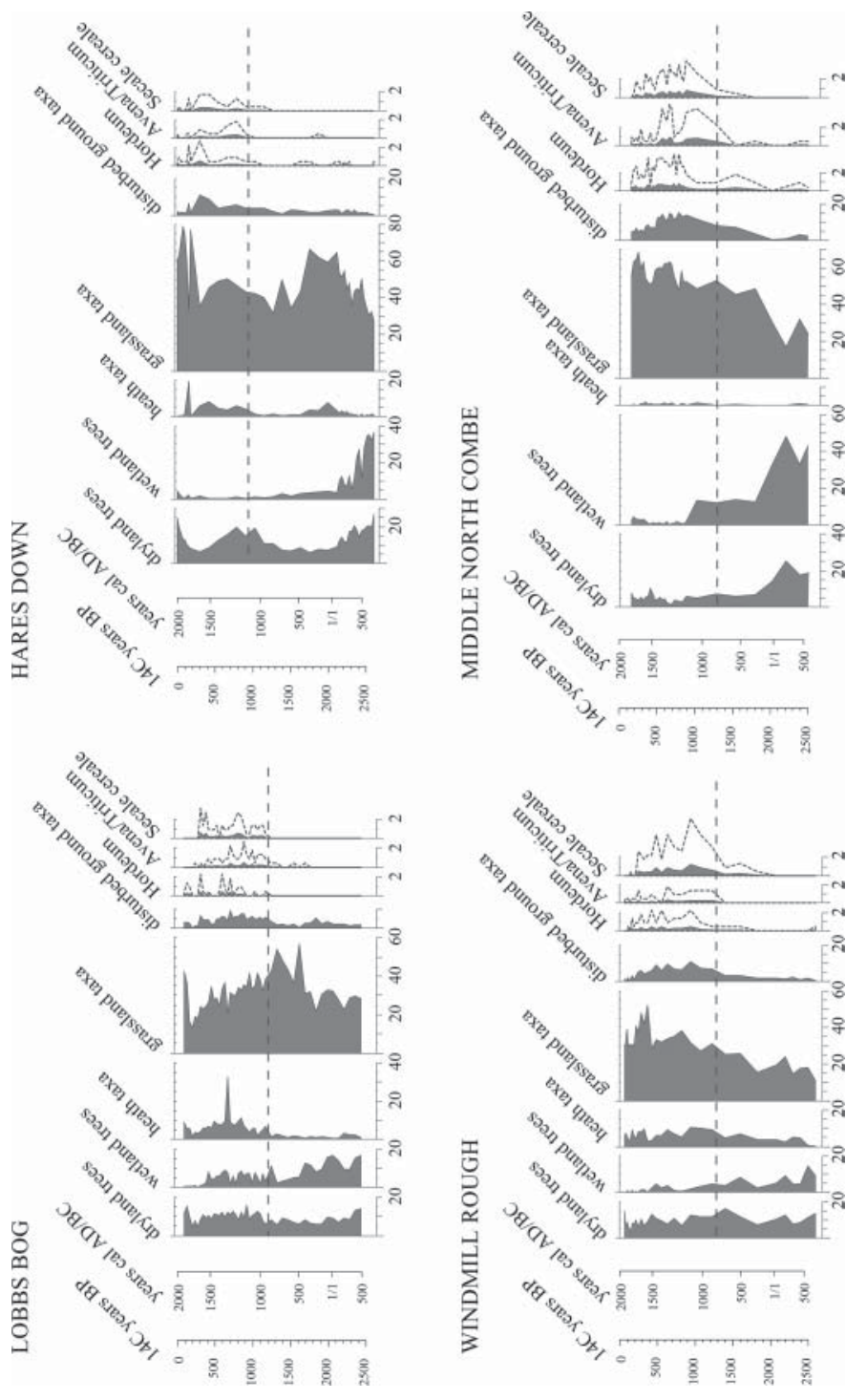

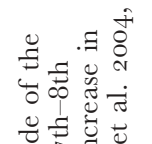
氙疋岂 氖导

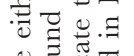

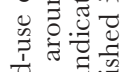

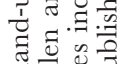
. . 정 . ㅁ․쿼 on कै चै

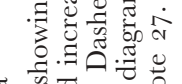
๙ ن. चु

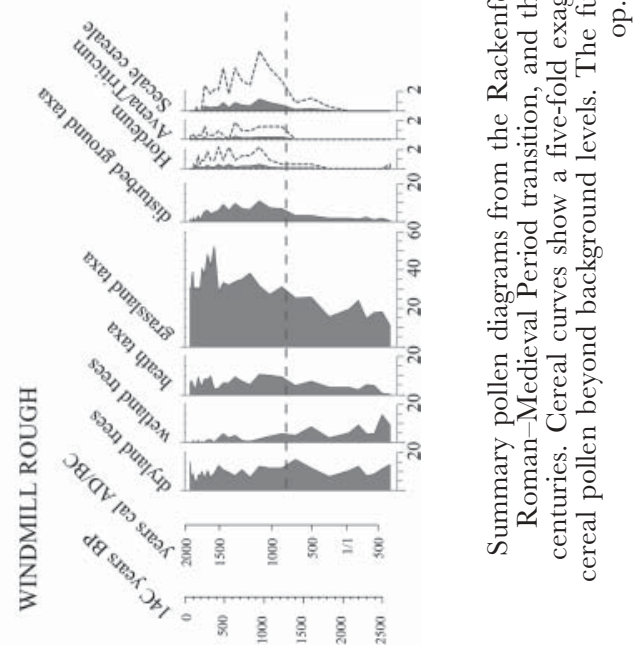




\section{ANSTEYS COMBE}

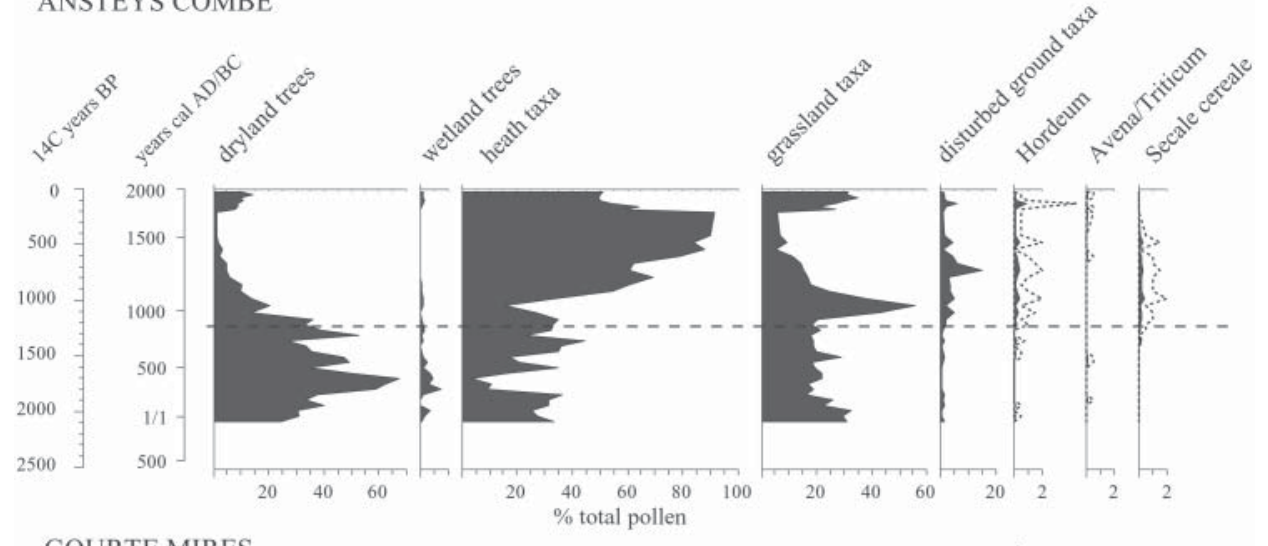

\section{GOURTE MIRES}

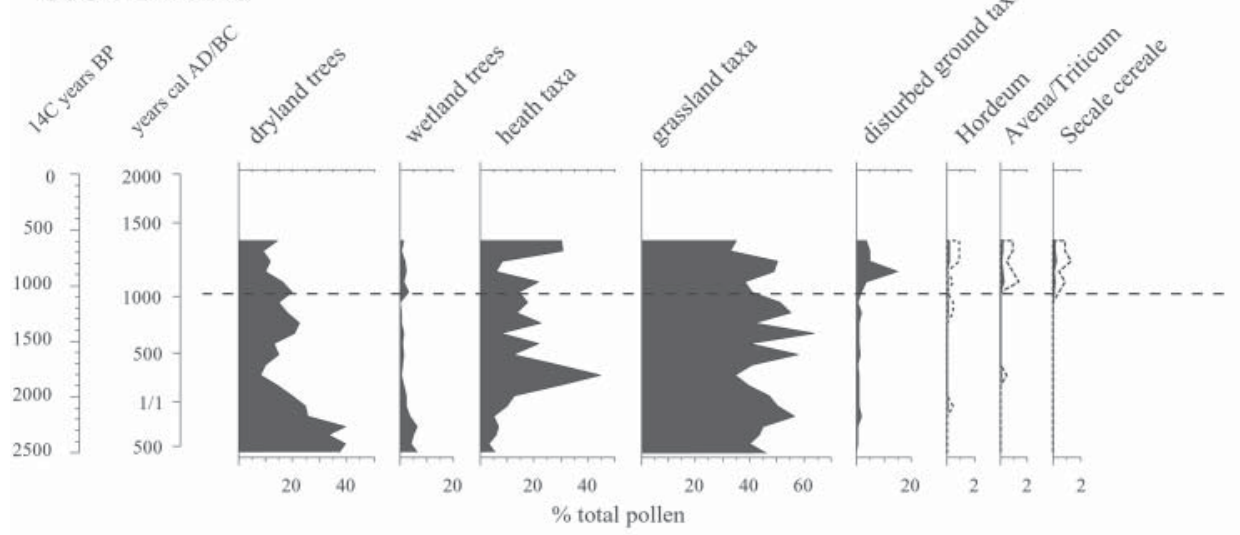

\section{LONG BREACH}

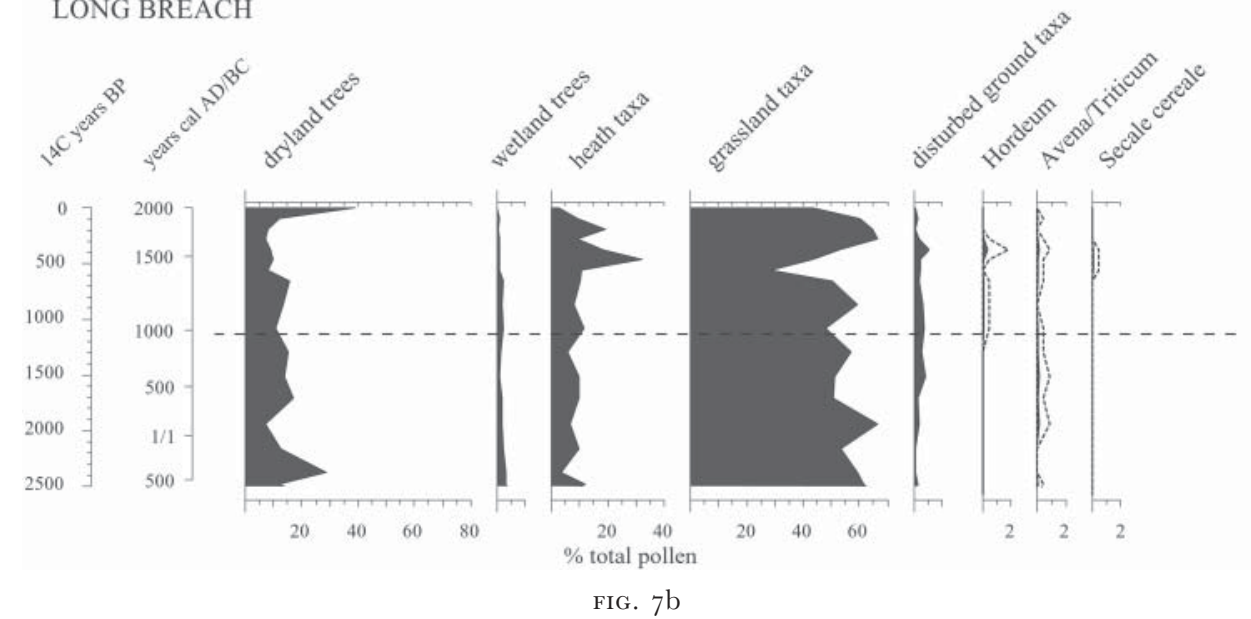

Summary pollen diagrams from the Molland area showing continuity in land-use either side of the

Roman-Medieval Period transition, and the marked increase in cereal pollen around the 7 th-8th centuries. Cereal curves show a five-fold exaggeration. Dashed horizontal lines indicate the increase in cereal pollen beyond background levels. The full pollen diagrams have been published in Fyfe et al. 2003, op. cit. in note 27 . 
the start of significant curves for cereal-types, notably Avena-Triticum-type (oats or wheat) and Secale cereale-type (rye). ${ }^{43}$ At Lobbs Bog these taxa each reach levels of around 2\% total land pollen (TLP); at Windmill Rough Secale cereale is recorded at levels up to $5 \%$ TLP, while at Middle North Combe Avena-Triticum-type is recorded at up to $5 \%$ TLP and Secale cereale at up to $4 \%$ TLP. These figures for rye and wheat compare to typical values of around $\mathrm{I} \%$ or less for lowland Devon in the later ist millennium A.D., ${ }^{44}$ and as cereal pollen does not travel far the relatively high percentages in the Rackenford sequences suggest cultivation within a kilometre. ${ }^{45}$ Notoriously, cereal pollen is poorly dispersed beyond the immediate location of cultivation; the values recorded must represent continuous and extensive arable cultivation in the immediate vicinity of the sites. In the three Rackenford diagrams there are also significant levels of herbaceous taxa associated with arable cultivation, notably Anthemis-type. Hordeum-type pollen is also recorded in each of these sequences from the same date. Although the Hordeum-type group contains cultivated species (e.g. Hordeum vulgare: domestic barley) it also includes grasses characteristic of wet flushes and fens, such as the Glyceria group, and so is a less reliable indicator of arable cultivation. At Windmill Rough, and to a lesser extent Lobbs Bog, the increase in cereal indicators in the diagrams is also associated with an increase in species characteristic of fen environments (e.g. Filipendula, Hypericum elodes, Menyanthes trifoliata and Potamogeton), lending further caution to the interpretation of the Hordeum-type as an arable indicator. At Windmill Rough and Lobbs Bog, there is also an increase in Calluna (heather) around the 7 th-8th centuries reaching up to around I $\%$ TLP, suggesting open grazing and possibly the use of fire in the unenclosed land.

At Hares Down there is a further decline in Alnus (alder) around the 7 th8th centuries, suggesting the removal of streamside and flush wet woodland, along with an increase in heather, although a constant cereal curve does not appear until around the Ioth century. ${ }^{46}$ This decline in alder is not climatically induced, as these are groundwater-fed mires, not rainfall-fed raised bogs. The later date for the appearance of cultivation near Hares Down is in keeping with evidence from the Romano-British Period where there was a slightly greater amount of woodland remaining in what was a rather more steeply sided valley compared to Lobbs Bog and Windmill Rough.

Pollen evidence for cereal cultivation first appears on the southern fringes of Exmoor around the Ioth-I Ith centuries, some 200-300 years later than in the Rackenford lowlands. This evidence is not restricted to occasional grains at trace levels, and cereal pollen is recorded at levels of around $2 \%$ TLP. While it is possible that some other elements of the pollen assemblages on the southern Exmoor fringe represent grains blown up the southerly draining combes to the

\footnotetext{
${ }^{43}$ Fyfe et al. 2004, op. cit. in note 27.

${ }^{44}$ Caseldine et al., op. cit. in note I9, I I 3; Caseldine et al., op. cit. in note I 8, 65-7; Hatton and Caseldine, op. cit. in note 20; V. Straker, 'Sourton Down, a study of local vegetation change and human impact on the landscape: pollen analysis of buried soils, sediments and peat', I I 4-I7 in P. J. Weddell and S. J. Reed, 'Excavations at Sourton Down Okehampton i 986-r 99 I', Proc. Devon Archaeol. Soc., 55 ( 1997), 39-1 47.

${ }^{45}$ Following Heim cited in D. Austin, R. H. Daggett and M. J. C. Walker, 'Farms and fields in Okehampton Park, Devon: the problems of studying medieval landscape', Landscape Hist., 2 ( I 980), 39-58; Vuorela, op. cit. in note 36 .

${ }^{46}$ Hares Down: io8o \pm 50 B.P., cal. A.D. 860-I 280: Fyfe et al. 2004, op. cit. in note 27.
} 
sites, the poor production and dispersal of cereal pollen (described above) must reflect the actual extension of cereal cultivation on to the upland. At Gourte Mires, there is a rise in cereal pollen-types (Secale cereale- and Avena-Triticum-type) associated with the weeds of cultivation, at the same time as species associated with pastoral land-use decline, and there is a reduction in microscopic charcoal suggesting a cessation of burning on the uplands. ${ }^{47}$ At Anstey's Combe the same expansion in arable cultivation is also associated with a marked decline in the oak-dominated woodland and shift to open heather-dominated heath. ${ }^{48}$ As with the Rackenford sites, the cereal pollen, notably Secale cereale (rye), is not restricted to occasional grains but is present in significant amounts and is highly unlikely to represent pollen simply blown up the valleys but rather some cultivation of the valley sides. Cereals also appear at Long Breach at around this date, though at lower levels than at the lower-lying Anstey's Combe and Gourte Mires, and the main peak in Secale cereale dates to the High Middle Ages. ${ }^{49}$ The late appearance and low levels of cereal pollen at Long Breach can be explained by its location, being the highest of the pollen sites and the furthest from areas of medieval settlement.

\section{INTERPRETING THE INGREASE IN GEREAL POLLEN}

One interpretation of this increase in cereal pollen is a classic 'push into the margins': that the arable cultivation associated with settlements located in more favourable locations was expanding into these areas that were less suited to cultivation and had now reached the catchments of these peat bogs. This may in part have been the case in the Ioth-I Ith centuries at the steeply sided Anstey's Combe, where there was a decline in woodland at the same time as an increase in cereals. The Molland sites generally, and most notably Long Breach, are also at the upper margins of the medieval settled landscape and so may indeed relate to some expansion of agriculture on to what had previously been open moorland. Such a 'push into the margins' interpretation is, however, unlikely to have been the case elsewhere, and particularly in the lowlands around Rackenford in the 7 th-8th centuries which all lie in areas of Mid-Devon that were extensively settled by Domesday. Middle North Combe in particular lies immediately adjacent to a potential medieval farmstead, and the surrounding historic landscape is one of small, irregularly shaped closes whose morphology suggests they are of considerable antiquity (Fig. 8). Lobbs Bog, Hares Down and Windmill Rough are, however, c. I km from the nearest documented medieval settlements, and although some relict field systems survive as earthworks there are no deserted farmsteads. If permanent arable land had expanded from these farmsteads as far as the pollen sites, and if this intensity of cultivation is applied across the rest of the South-West, then virtually the whole of lowland Devon and Cornwall would have been under the plough! This cannot have been the case and there must have been another system of landscape management causing such high cereal pollen values here.

${ }^{47}$ Gourte Mires: r $020 \pm 6$ o B.P., cal. A.D. 890-1 I 70: Fyfe et al. 2003, op. cit. in note 27.

48 Anstey's Combe: i i $\overline{60} \pm 70$ B.P., cal. A.D. 680-1020: Fyfe et al. 2003, op. cit. in note 27.

${ }^{49}$ Long Breach: $650 \pm 60$ B.P., cal. A.D. I 270-I 420 : Fyfe et al. 2003, op. cit. in note 27. 


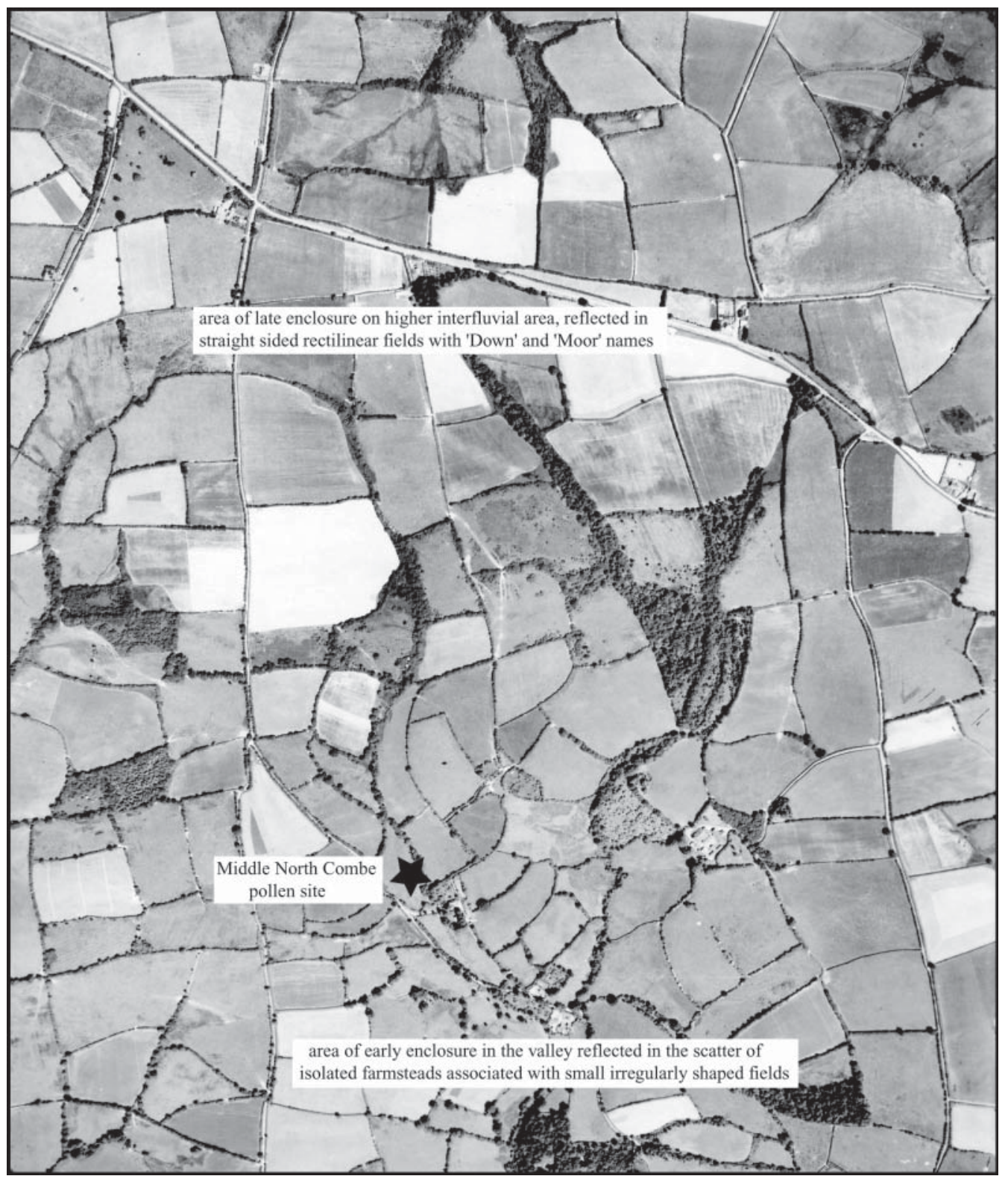

FIG. 8

Aerial photograph of the Middle North Combe area (NMR ${ }_{3} \mathrm{G} / \mathrm{TUD} / \mathrm{UK}_{22}$ I Part III I I July I 946 frame 5303). The dispersed settlement and small irregularly shaped closes are typical of lowland Devon, and the pollen site lies at the heart of this landscape (see Fig. 9). (C) English Heritage (NMR) RAF Photography. 
The palaeoenvironmental evidence itself also does not support a solely 'push into the margins' interpretation. If there had been a simple expansion of arable cultivation, then there should have been an equivalent decline in woodland and pasture, but this is not the case. All the sites show the continuation of a rich pastoral flora, and woodland still present, with no reduction corresponding to the increase in arable (apart from Anstey's Combe). The pollen record shows not just a sharp increase in cereal, but also an expansion of heather at Hares Down, Lobbs Bog and Windmill Rough (though not Middle North Combe), which is unlikely to have been growing on the peat bogs themselves as macrofossil evidence suggests they were dominated by sedges. The presence of heather at these sites is most likely to represent rough grazing on the most marginal land outside the main agricultural holdings (whereas the lower-lying Middle North Combe lay in an area within which virtually all the land within its pollen catchment was agriculturally improved: Figs. 8-9).

The appearance of such a strong cereal component in these pollen sequences without an equivalent significant decline in woodland/pasture does not represent, therefore, a simple expansion of cereal cultivation. As these valley mires were never drained, it must reflect a new system of agriculture that brought arable farming close to the peat bogs, but within a regime that still included a strong pastoral component alongside areas of woodland and heath. This is precisely what we know to have existed in the South-West by the Late Middle Ages. From around the mid-I 4th century, we have good documentary evidence for the character of medieval agriculture in the region. It is clear that they practised a distinctive system of rotational cropping known as 'convertible husbandry'. Within this the majority of fields (closes or parcels of open fields) were subject to alternating grain and grass crops, often with a short period of cultivation (c. 2-3 years) followed by a long grass ley (c. 6-8 years), producing a rotation of around ten years. ${ }^{50}$ About a quarter of fields would have been cultivated in any one year, and very few fields (if any) within this core 'infield' area of intensive farming would have been permanent pasture. Beyond the 'infield' sometimes lay areas of rough grazing land in the 'outfield', which was occasionally ploughed at times of particularly high demand.

In the convertible husbandry regime, before new fields were ploughed, the old ley grass, turf and all, was stripped off, dried and then burnt, a process known as beat-burning. Removal of the turf made ploughing easier, and the ashes could be returned to the soil to improve fertility, sometimes having been mixed with other dressings such as farmyard manure, sea sand and seaweed. This method of maintaining soil fertility, along with the long-lived regional tradition of growing oats and rye as the coarse-grain ingredients in the diet, probably accounts from the absence of legumes from medieval crop rotations in Mid- and northern Devon. ${ }^{51}$ Documentary sources support the pollen evidence in showing that oats and rye were the major crops during the High Middle Ages,

${ }^{50}$ H. S. A. Fox, 'Farming practice and techniques, Devon and Cornwall', 303-23 in E. Miller (ed.), The Agrarian History of England and Wales, vol. 3, I348-I50o (Cambridge, I 99 I); H. S. A. Fox and O. Padel, The Cornish Lands of the Arundells of Lanherne, Fourteenth to Sixteenth Centuries (Devon and Cornwall Records Society 4I, 200o).

${ }^{51}$ Fox, op. cit. in note 50, 305-6. 


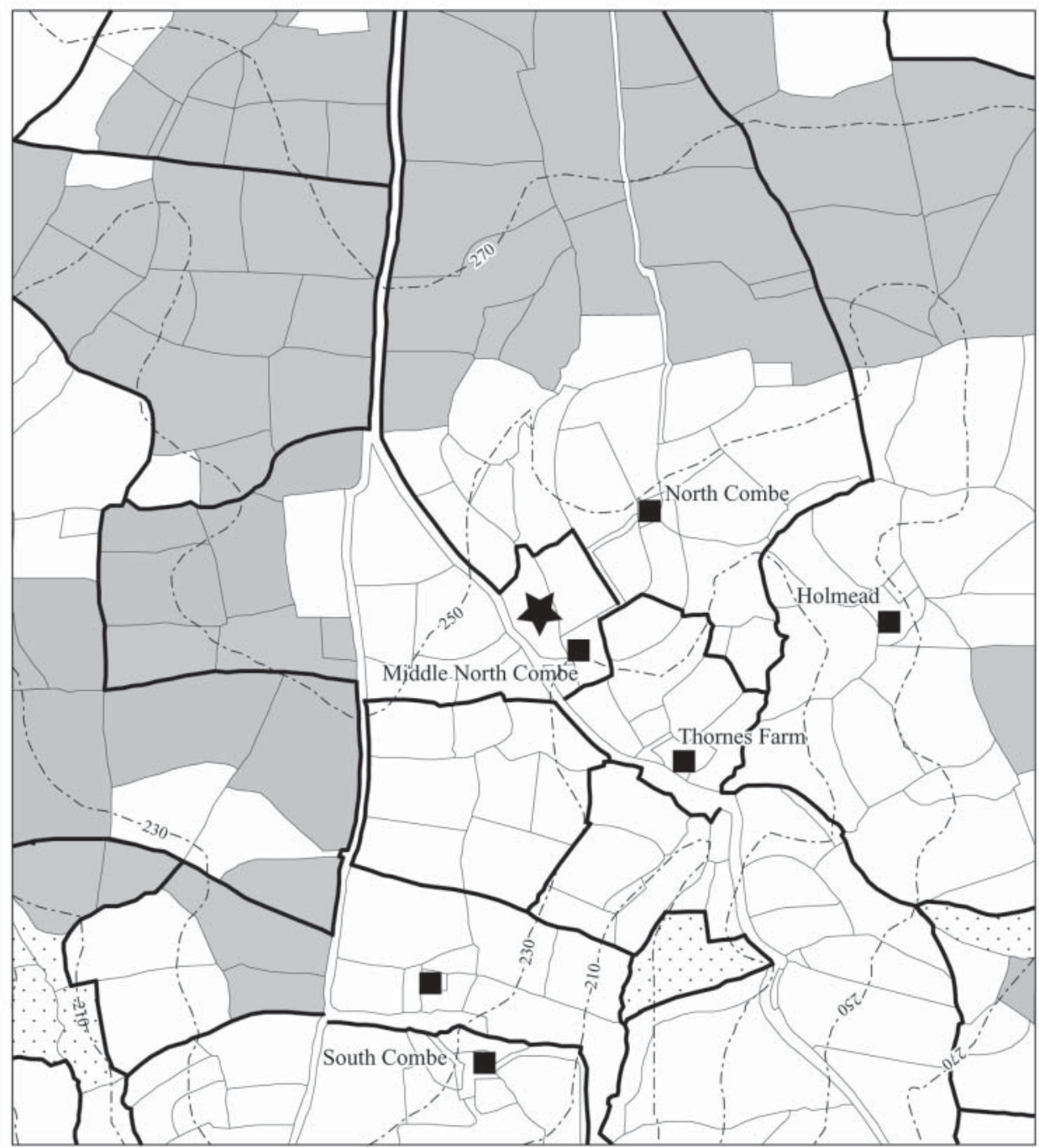

Tithe map field-names with -moor, -acre or -down element indicating areas of relatively late enclosure

$\square$ wood or coppice on Tithe Map

contour (at $20 \mathrm{~m}$ intervals)

farmstead

$\checkmark$ pollen site (Middle North Combe)

North

boundaries of land holdings on Tithe map.

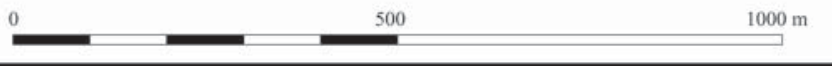

FIG. 9

The historic landscape around Middle North Combe based on the Tithe Map, with the compact landholding of each farmstead marked by a bold line. Note how the pollen site lies well within the area of ancient enclosure. Larger, rectilinear fields with 'Moor' and 'Down' names tend to occur on the higher interfluvial areas and are suggestive of relatively recent enclosure of what was open rough grazing. 
and that this was not simply because they were ideally suited to areas with acid soils, cool summers and high rainfall, as in later centuries barley and wheat were also grown very successfully in the region. Rather, the dominance of oats and rye reflects their high yields (higher than the national average for these crops) and the traditional local preference for their use in bread and beer that was well established and slow to change. ${ }^{52}$ In the Late Middle Ages, oats $(42 \%$ of demesne cropping) continued to be grown in mid- and northern Devon alongside rye $(37 \%)$ and wheat $(2 \mathrm{1} \%) .{ }^{53}$ Excavated macrofossils from the uplands of Dartmoor at Hound Tor, ${ }^{54}$ and on the Culm Measures of western Devon at Sourton Down, ${ }^{55}$ similarly show that oats predominated, while oats and rye were the principal crops in the extensive deposits of charred grain from a 12 thcentury granary excavated at Lydford. ${ }^{56}$ Secale-type also dominated the pollen assemblage at Holne Moor on Dartmoor, with some Triticum (wheat) but no Hordeum-type (potentially barley-type) or Avena-type (oats). ${ }^{57}$ At Okehampton Park, Hordeum-type dominated the pollen (alongside some Secale-type and possibly Avena-type and Triticum-type). ${ }^{58}$ However, its interpretation as barley must be questionable in this wet upland context. Although the Hordeum-type group contains cultivated species (e.g. Hordeum vulgare: domestic barley), it also includes grasses characteristic of wet flushes and fens, such as the Glyceria group (see above), and coincident with the Hordeum-type increase at Okehampton Park is indeed a rise in other species typical of wet or waterlogged ground, including Potamogeton (pondweeds) and Caltha palustris (marsh marigold). Only on the warm, fertile soils of the South Hams does wheat appear to have predominated in Devon. ${ }^{59}$ Cattle rearing dominated livestock husbandry in Mid- and northern Devon; cows and young bovines comprised $22 \%$ of the total numbers of cattle and sheep, compared to $12 \%$ in eastern and southern Devon. ${ }^{60}$

So what does convertible husbandry look like in the pollen record? Documentary sources suggest that this regionally distinctive system of rotational cropping was ubiquitous throughout the South-West, as far east as the Blackdown and Quantock Hills. This means that those sections of these peat bogs dating from the $\mathrm{I} 4^{\text {th }}$ century (the earliest period for which convertible husbandry is clearly documented) will reflect how convertible husbandry shows up in the pollen record. The $5 \mathrm{~mm}$ thick samples of peat used in the pollen analyses will represent between five and ten years of pollen accumulation.

52 B. M. S. Campbell, English Seigniorial Agriculture, I250-I 450 (Cambridge, 2000), 252-6I; H. P. R. Finberg, Tavistock Abbey: A Study in the Social and Economic History of Devon (Newton Abbott, I 969), 86- I I 5; Fox, op. cit. in note 50, 303-8.

${ }^{53}$ Campbell, op. cit. in note 52, 285; Finberg, op. cit. in note 52, 86-I I 5; Fox, op. cit. in note 50, 303-9.

${ }^{54}$ G. Beresford, 'Three deserted medieval settlements on Dartmoor: a report on the late E. Marie Minter's excavations', Medieval Archaeol., 23 ( 1979), i 43.

${ }_{55}$ Straker, op. cit. in note 44 .

56 Ibid., I I 6.

${ }^{57}$ D. Maguire, N. Ralph and A. Fleming, 'Early landuse on Dartmoor: palaeobotanical and pedological investigations on Holne Moor', 57-106 in M. Jones (ed.), Integrating the Subsistence Economy (BAR Internat. Ser. I 81, Oxford, I983).

58 Austin et al., op. cit. in note $45,48$.

${ }^{59}$ I. D. L. Foster, T. M. Mighall, C. Wotton, P. N. Owens and D. E. Walling, 'Evidence for mediaeval soil erosion in the South Hams region of Devon, UK', The Holocene, ro(ii) (2000), 26I-7I.

60 Fox, op. cit. in note 50, 316. 
During this period, fields immediately adjacent to the mires are likely to have been cultivated for several years, leading to the high representation of cereals and other arable indicators, with the intervening ley periods resulting in the constant pasture signature in the pollen sequences (Fig. I 3). It has been observed that in the Post-medieval Period, when documentary sources suggest that convertible husbandry continued to be practised, the pollen sequences all show a decline in cereal pollen. But crucially, cereal cultivation does not disappear altogether and the distinctive signature of convertible husbandry - arable cultivation alongside large areas of improved pasture, and small amounts of woodland and heather-rich moorland - remains. The decline in cereal pollen is likely to reflect a reduction in the proportion of land that was cultivated, rather than a fundamental change in the way that agriculture was practised (i.e. the abandonment of convertible husbandry). Crucially, having recognised the convertible husbandry signature from I4th-century and later horizons, an examination of the earlier samples reveals no differences in landscape management between then and the onset of significant cultivation in the 7 th-8th centuries around Rackenford. It would appear, therefore, that convertible husbandry may have been introduced in the lowlands of Devon at this date, and several centuries later in the upland fringe.

\section{THE HISTORIG LANDSGAPE ASSOGIATED WITH GONVERTIBLE HUSBANDRY}

We can still see evidence for the practice of convertible husbandry within the physical fabric of the historic landscape (Figs. 8-I2). The configuration of field boundaries and patterns of landownership recorded in the Tithe surveys of c. I840 suggests that most farmsteads within the study areas were associated with a compact block of closes held in severalty. Typically these were divided between around eight to twelve closes which are defined by roughly oval, lobeshaped or sub-rectangular enclosures seen both around Rackenford (Bickham, Windsor Farm, Blindwell, Rackenford Moor, Canworthy, Brownsford, South Roachill and Higher Swineham: Fig. I I) and Molland Common (East Ringcombe, Ringcombe, Brimblecombe, Landcombe, the Lyshwell, Cloggs and Moorhouse: Fig. I2). In between these areas of enclosure, often on the higher interfluvial areas, there were areas of unenclosed rough grazing that was occasionally cultivated as an 'outfield' (a practice that is well documented on Exmoor and in the South-West as a whole). ${ }^{61}$ The pollen site at Middle North Combe, for example, actually lies within the closes of Middle North Combe Farm, whose landholding extends up on to the higher interfluvial areas which on the Tithe survey are characterised by larger, more rectilinear fields with a predominance of 'Moor' and 'Down' fieldnames, that taken together is suggestive of post-medieval enclosure (Fig. 9). Relict field systems at Hares Down and around the Molland Common pollen sites show that these areas were also formerly part of the enclosed fieldscape. While there is no surviving evidence for

${ }^{61}$ H. S. A. Fox, 'Outfield cultivation in Devon and Cornwall: a reinterpretation', r $90-38$ in M. Havinden (ed.), Husbandry and Marketing in the South-West I500-I80o (Exeter, I973); O. Hallam, 'Vegetation and land use on Exmoor', Proc. Somerset Archaeol. Natur. Hist. Soc., I 22 (1978), 37-5 I. 
this at Lobbs Bog and Windmill Rough, the pollen evidence from all of these sites is not compatible with the cereals simply representing the periodic cultivation of an 'outfield'. The constant and relatively high cereal count, and associated weeds of arable cultivation, sits alongside improved pasture (as indicated by species such as knapweed and ribwort plaintain), which suggests good grazing land ploughed within a rotation system, rather than rough grazing land occasionally taken in. The pollen diagrams record heath species, which may lend weight to the alternative interpretation of periodic cultivation of an 'outfield', although it can equally be argued that these represent permanent rough grazing on the nearby high interfluvial commons.

A wide range of evidence shows that during the Medieval Period the agricultural land that supported convertible husbandry in the South-West was arranged in both open- and enclosed field systems. Within the study areas, though, only the latter appears to have been the case with most farmsteads associated with a cluster of small, rectangular or more irregularly shaped fields called 'close', 'park' and 'gratton' that were clearly farmed in severalty (e.g. around Middle North Combe: Figs. 8-9). Occasionally the land immediately around a farmstead is divided up by one or more sinuous coaxial boundaries around which form the skeleton for small squarish or rectangular fields, sometimes with slightly curving boundaries, and similarly called 'close', 'park' and 'gratton' (e.g. South Roachill: Figs. Io-I I). In some places (for example elsewhere in Parracombe) the area between these co-axial boundaries is divided up into small blocks of longer, narrower fields with curving boundaries that are suggestive of strips within a former open field. In places the squarish closes may represent the amalgamation of several such former open field strips, as where not subject to recent intensive ploughing they sometimes contain the earthworks of low banks forming long, narrow, curving strip-like sub-divisions. ${ }^{62}$ These strips, known as 'landscores' (i.e. 'land-shares', or a sub-division of an open field) occur in blocks that in a late I 8th-century survey of Challacombe, on Dartmoor, are referred to as 'Wares', perhaps equivalent to the 'furlongs' in Midland open fields, but on a far smaller scale. ${ }^{63}$ These field systems suggestive of small-scale open fields are usually associated with hamlets, and in the Tithe surveys also show a distinctively fragmented pattern of landownership, with the holdings of an individual farm interspersed with those of its neighbours. It is easy, however, to over-emphasise the extent of these small open-field systems in the SouthWest. None, for example, exist within the study areas mapped in Figures 9, I I and I 2, all of which are characterised by squarish closes and compact landholdings associated with isolated farms. It is also important to stress that the open fields of the South-West were on an altogether different scale to those in the

${ }^{62}$ A. Fleming and N. Ralph, 'Medieval settlement and landuse on Holne Moor, Dartmoor: the landscape evidence', Medieval Archaeol., 26 ( I982), I I-37; M. Gillard, The Medieval Landscape of the Exmoor Region: Enclosure and Settlement in an Upland Fringe (unpubl. Ph.D. thesis, University of Exeter, 2002); P. Pattison, 'Challacombe revisited', 6 $1-70$ in P. Pattison, D. Field and S. Ainsworth (eds), Patterns in the Past (Oxford, I 999); Riley and Wilson-North, op. cit. in note 8, figs. 4. I 2-I 3, 4.30, 5.6, 5. I I-I 2; Rippon 2004, op. cit. in note 7, fig. 26.

${ }_{63}$ D. J. Bonney, 'Former farms and fields at Challacombe, Manaton, Dartmoor', 83-9I in K. J. Gregory and W. L. D. Ravenhill (eds.), Exeter Essays in Geography in Honour of Arthur Davies (Exeter, I97 I); Pattison, op. cit. in note 62,68 . 


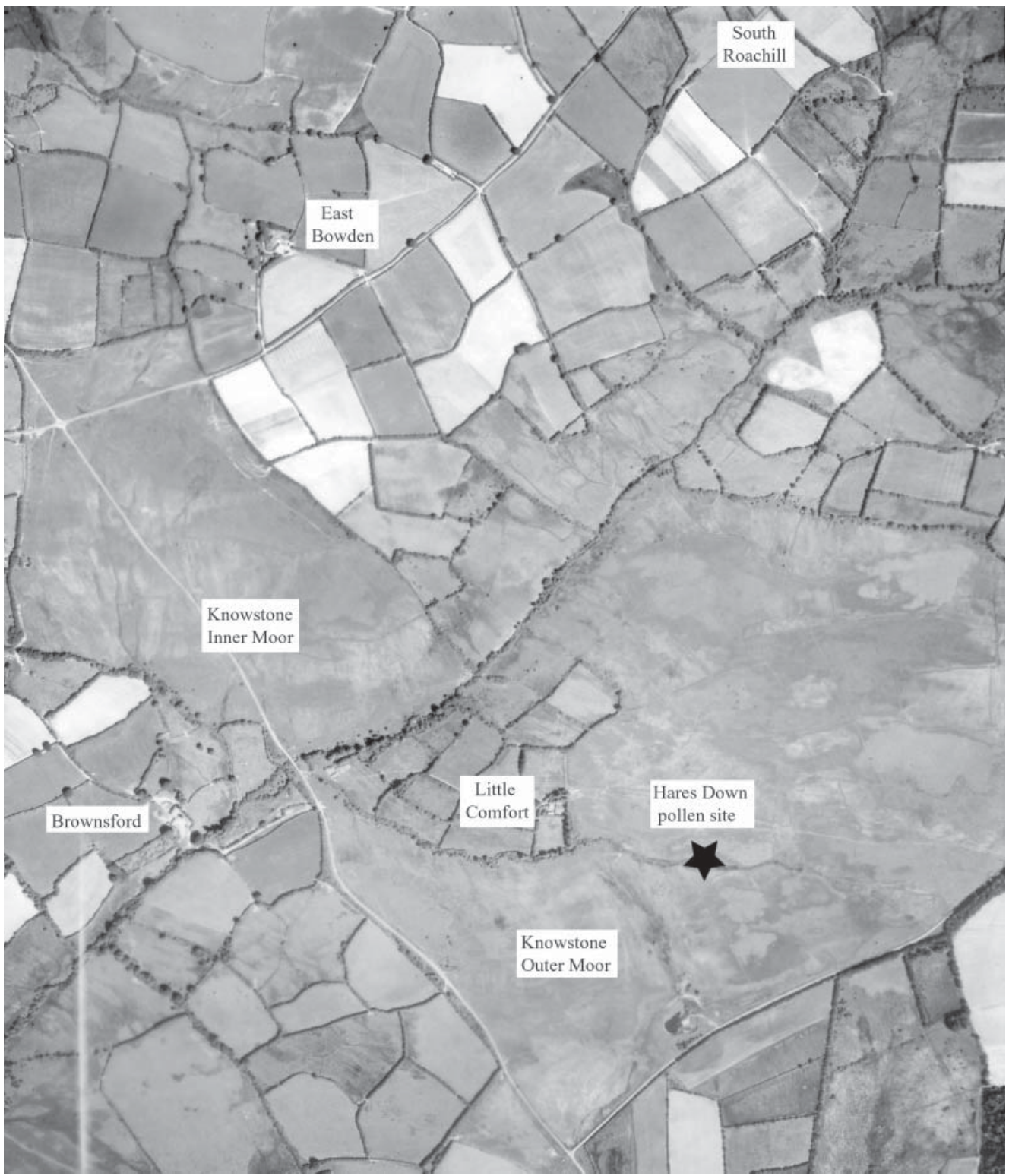

FIG. IO

Aerial photograph of the Hares Down area (NMR ${ }_{3} \mathrm{G} / \mathrm{TUD} / \mathrm{UK}_{22}$ I Part II I I July i 946 frame 5094). The pollen site lies just beyond the enclosed field systems of today, though the earthworks of an extensive relict landscape show that this area was once covered by a near continuous fieldscape (see Fig. I I).

(C) English Heritage (NMR) RAF Photography. 


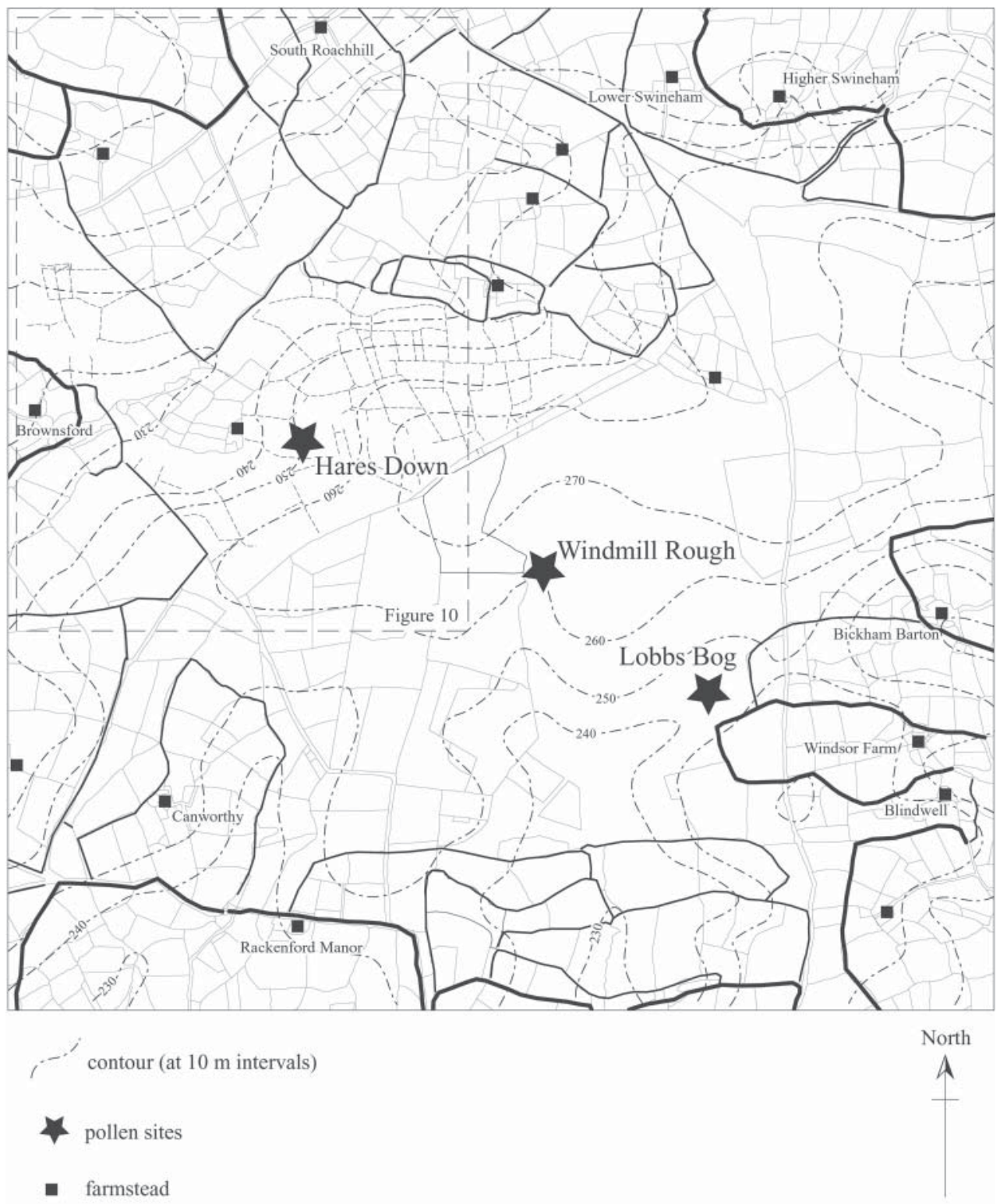

$\Gamma$ key boundaries in historic landscape representing the progression of enclosure of the watershed commons earthworks of relict landscape

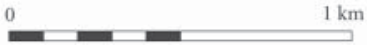

FIG. I I

The historic landscape around Rackenford Moor based on the Tithe Maps, with each farmstead associated with a compact landholding of closes held in severalty. A series of long, sinuous field boundaries (shown in bold) reflect the progressive enclosure of the moor. Areas of larger, more rectilinear fields, suggestive of more recent enclosure, can be seen to the south-west of Windmill Rough. Although the pollen sites currently lie in areas of open ground, the earthworks of relict field systems suggest that they were once within the enclosed landscape (see Fig. Io). 


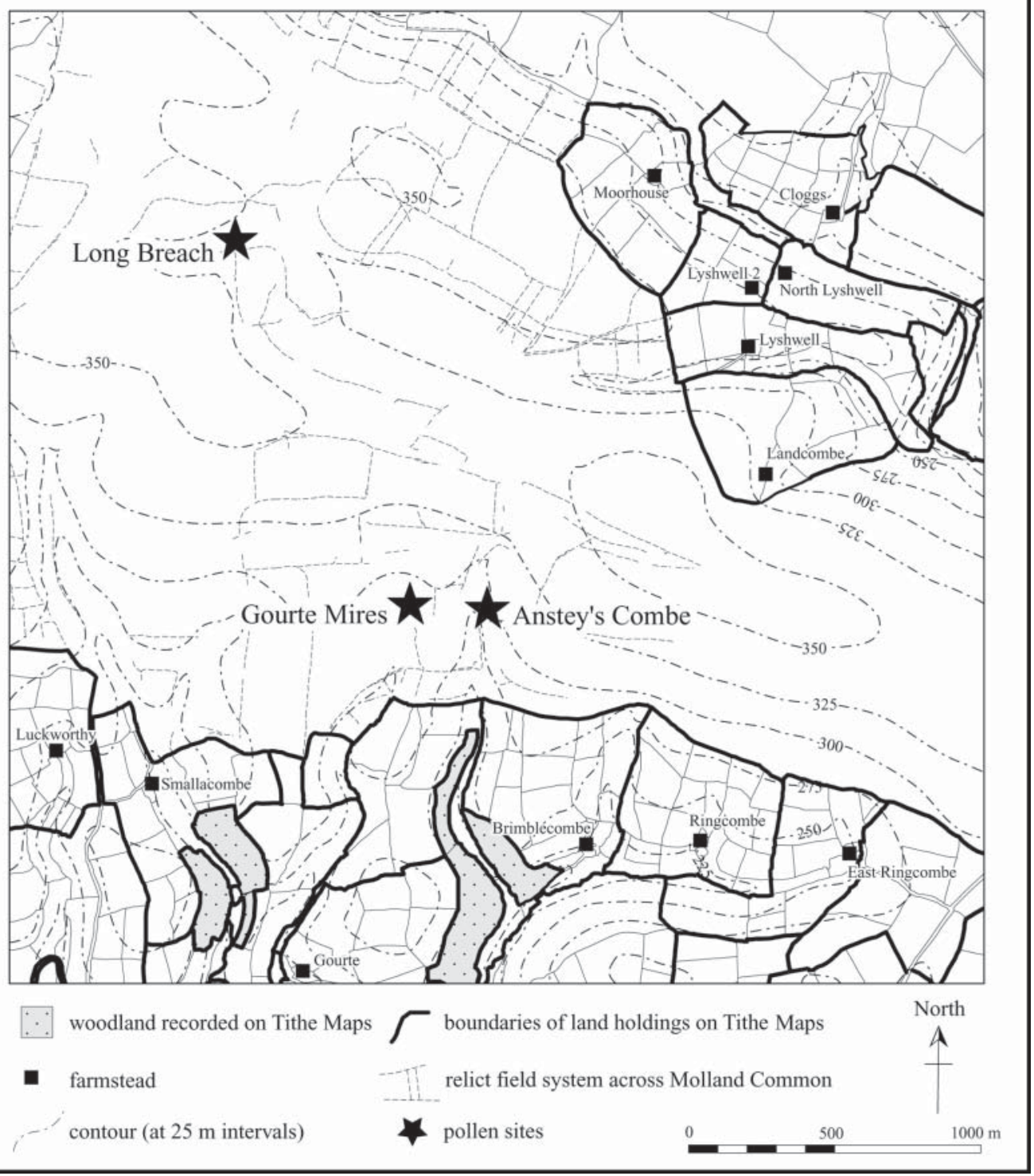

FIG. I 2

The historic landscape around the Molland Common pollen sites based on the Tithe Maps, with each farmstead associated with a compact landholding (marked by a bold line) of closes held in severalty (the 'infields'). The pollen sites currently lie in areas of open ground but are surrounded by the earthworks of relict field systems and plough ridges suggesting these areas were formerly the 'outfield' of farms such as Brimblecombe, Gourte, Smallacombe and Moorhouse. 


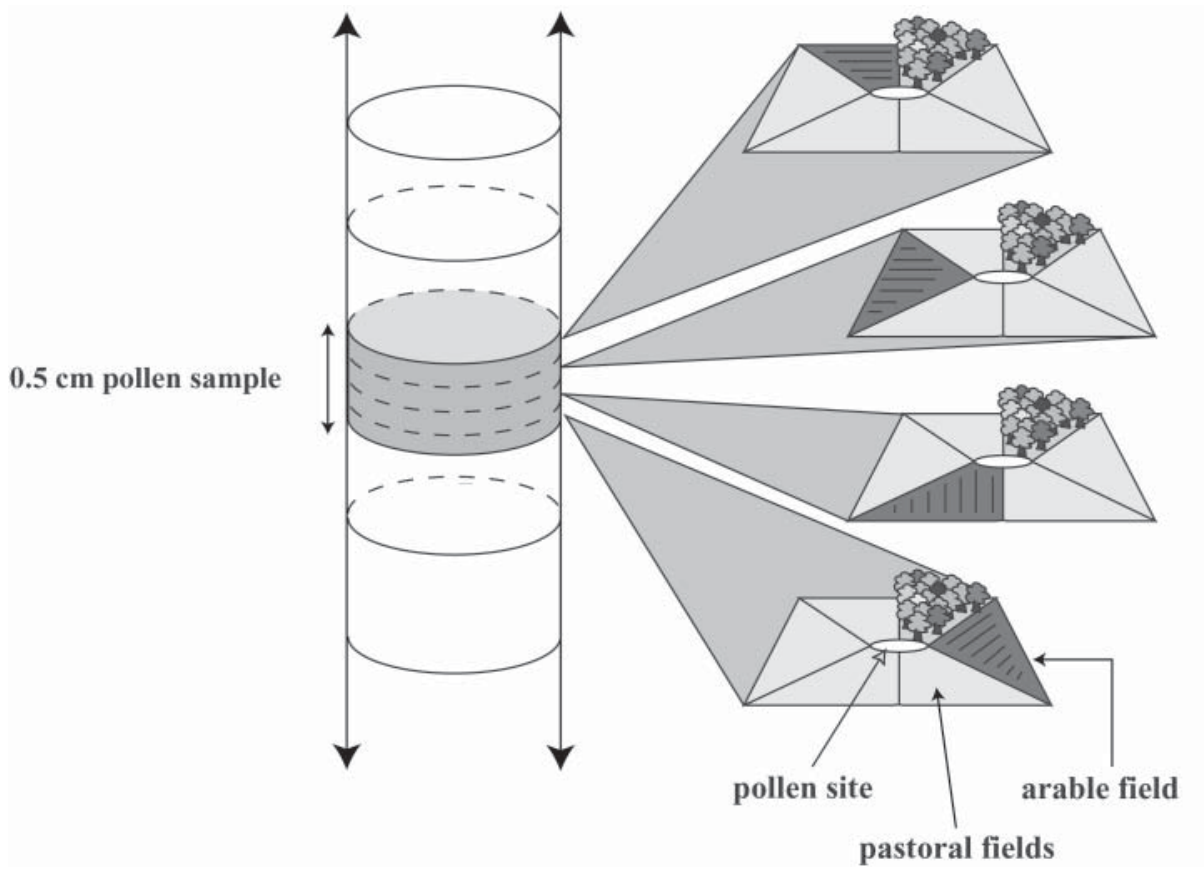

year 4

year 3

year 2

year 1

FIG. I 3

Schematic model for how the rotation-based system of convertible husbandry shows up in a pollen sequence taken from a small valley mire that was not itself drained and cultivated.

'Central Province'. The latter saw a single open-field system encompass virtually all the ploughed land within a parish, whereas in the South-West each hamlet within a parish had its own small-scale open field that often covered only part of its agricultural land (the rest being held in severalty in closes).

As suggested above, while small hamlets are a distinctive feature of the South-West's historic landscape, many areas are characterised by isolated farmsteads. In both Cornwall and Devon detailed historical research has shown that some of what are now isolated farms were small hamlets in the High Middle Ages ${ }^{64}$ but it would be wrong to assume that this was the case everywhere. Archaeological evidence suggests that the settlement pattern always contained both isolated farmsteads and small hamlets. ${ }^{65}$ Where hamlets, sometimes associated with probable open fields, are known to have shrunk to a single

${ }^{64}$ M. W. Beresford, 'Dispersed and grouped settlement in medieval Cornwall', Agric. Hist. Rev., I 2(i) ( I 964), I 3-27; Bonney, op. cit. in note 63; H. Fox, 'Peasant farmers, patterns of settlement and pays: transformations in the landscapes of Devon and Cornwall during the later Middle Ages', 4I-75 in R. Higham, Landscape and Townscape in the South West (Exeter, I989); Fox, op. cit. in note 50, I64.

${ }^{65}$ D. Austin, 'Excavations in Okehampton Park, Devon, I976-78', Proc. Devon Archaeol. Soc., 36 (I978), I 9 I-240; D. Austin, 'Dartmoor and the upland village of the South-West of England', 7 I-8o in D. Hooke (ed.), Medieval Villages (Oxford, I 985); Austin et al., op. cit. in note 45, 54; A. Fox, 'A monastic homestead on Dean Moor, South Devon, Medieval Archaeol., 2 (I958), I4 I-57; C. G. Henderson and P. J. Weddell, 'Medieval settlements on Dartmoor and in west Devon: the evidence from excavations', Proc. Devon Archaeol. Soc., 52 (I 994), I I 9-47; E. M. Jope and R. I. Threlfall, 'Excavation of a medieval settlement at Beere, North Tawton, Devon', Medieval Archaeol., 2 ( I 958), i 1 2-40; Pattison, op. cit. in note 62; Riley and Wilson-North, op. cit. in note 8, Ioo, I $3 \mathrm{O}^{-2}$; Weddell and Reed, op. cit. in note 44 . 
farmstead, the historic landscape often contains a distinctive signature with small paddocks and closes around the abandoned tofts (along with a fragmented pattern of landownership in the adjacent areas: see above). We do not find this in the study areas shown in Figures 9, I I and I 2. It is also not clear whether the small hamlets of the High Middle Ages were created as such in the Pre-conquest Period (when convertible husbandry appears to have been introduced), or whether they originated as isolated farmsteads that subsequently grew in size, as appears to have been the case at Okehampton Park on the northern fringes of Dartmoor. ${ }^{66}$ Overall, the emphasis within the settlement pattern is on one of dispersion, with the growth and decline of small hamlets over the course of the Medieval Period being a feature of some areas, but never approaching the degree of nucleation seen in the Midlands (the significance of which will be returned to later).

\section{THE LATE AND POST-MEDIEVAL PERIODS}

Perhaps surprisingly the pollen sequences from Rackenford, Molland Common and Parracombe show few signs of change in land-use during the Late Middle Ages, and at most sites the decline in arable cultivation appears to have occurred during the Post-medieval Period (Figs. 5-7). There are, however, changes in the Post-medieval Period and, while it was notable that in the Early Medieval Period the increase in arable was remarkable synchronous across sites in the same cluster, the post-medieval changes were more varied. Around Rackenford the decline in arable did not occur until around the I6th-I8th centuries. ${ }^{67}$ All the sites show the continuation of pastoral land management: grasses dominate the Middle North Combe and Hares Down sequences, while at Lobbs Bog and Windmill Rough the dominance of sedges alongside grasses suggest a somewhat wetter local environment that today we would regard as typical Culm grassland (a nationally scarce, species-rich, pastoral community). There is a general decline in values of hazel during this period and while oak continues to be recorded at low levels at all the sites, it increases slightly at Middle North Combe and Hares Down. Two sites (Middle North Combe and Lobbs Bog) also record a small peak in bracken shortly after the decline in arable indicators, suggesting a decrease in grazing intensity or a shift towards cattle husbandry.

On the southern and western fringes of Exmoor the timing of the cessation of cereal cultivation is less clear. At Long Breach, the highest of the Molland Common sites, the decline in Secale cereale (rye) is surprisingly late, being broadly synchronous with the rise of pine which is estimated to be around the second half of the i 8th century when plantations were established in the area. Heath vegetation increases and there is a decline in grassland herbs including Centaura nigra and Lactuceae, suggesting that enclosed agricultural land was abandoned. At Anstey's Combe rye also disappears as late as the pine rise, but heathland vegetation also declined although heather remains the dominant taxon. Grassland (including Poaceae, Ranunculus acris-type and Lactuceae) and oak/hazel woodland increases. This local difference between sites suggests an upland fringe

${ }^{67}$ Windmill Rough: $240 \pm 50$ B.P., cal. A.D. I 490-I949; Hares Down: interpolated date of c. 500 B.P. 
with a mosaic character: the unenclosed areas were probably a combination of heath and grass (Molinia) moorland and regenerating scrubby woodland, depending on local variation in topography, drainage and grazing intensity. This post-medieval decline in arable and increase in moorland vegetation may provide a context for the abandonment of the higher interfluvial areas at Rackenford and Molland Common evidenced by the relict landscapes there (Figs. IO-I2).

At Higher Holworthy in Parracombe there is an expansion in heather and some decline in the indicators of grassland and cultivation around the $\mathrm{I}^{\text {th }}$ centuries, which might suggest the abandonment of some agricultural land; a reduction of charcoal might also suggest less management of the moorland. Cultivation, however, continued as late as around the igth century when an increase in charcoal may indicate increased heathland management through controlled burning (known as swaling). ${ }^{68}$ At Twineford Head Combe there is possibly a shift from heather- to grass-dominated heath in the $15^{\text {th }}$ century, perhaps reflecting changes in management of upland grazing, but the extent of arable cultivation remains the same until around the i6th century when it declines along with the grassland. As heather increases there may have been some contraction in the area of enclosed agricultural land. A further rise in heather and slight decline in pasture occurred around the i 8th century, which was reversed around the igth century. These most likely represent variations in grazing intensity on the uplands though throughout this period some cultivation continued.

Overall, there appears to have been continuity in most aspects of landscape management, including arable cultivation, until around the i 6 th century. Thereafter there was some contraction in the area of agricultural land and fluctuations in the management of the open moorland (though the land that was still cultivated appears to have been managed as part of the same convertible husbandry regime with cereal cultivation alternating with improved grassland). This decline in arable cultivation during the Late Middle Ages is also recorded in documentary sources; in mid- and northern Devon as a whole, for example, c. $70 \%$ of demesne land was 'arable' (i.e. part of a convertible husbandry rotation) in the early $\mathrm{I} 4^{\text {th }}$ century, compared to $5 \mathrm{I} \%$ in the late $\mathrm{I} 5^{\text {th }}$ century. ${ }^{69}$ This no doubt reflects how demesne managers were to some extent reacting to reduced demand for cereals by shifting to pastoral farming. But it is also notable that in these pollen sequences the decline in arable is balanced by an increase in the amount of moorland (rising from $9 \%$ to $3 \mathrm{I} \%$ ), suggesting a retreat from the more marginal areas, but that within areas still occupied the proportion of arable and pasture altered little. The pollen evidence may in fact suggest even greater stability in the significance of arable within the landscape as a whole, compared to the rather fragmentary documentary sources that derive largely from certain demesnes on the larger estates whose shift from arable to pasture may have been more pronounced than on smaller holdings. ${ }^{70}$ 


\section{DISGUSSION: REGIONAL TRAJEGTORIES IN LATE IST-MILLENNIUM A.D. LANDSCAPE CHANGE}

By the Late Middle Ages the South-West had a distinctive system of agriculture, known as convertible husbandry, which was practised within a historic landscape characterised by a mostly dispersed settlement pattern of small hamlets and isolated farmsteads, surrounded by a mixture of open- and enclosed field systems. The origins of convertible husbandry are not recorded. All we can say from documentary sources is that it was in place by the $14^{\text {th }}$ century. But the palaeoenvironmental evidence presented here suggests that this distinctive system of land management came into being around the 7 th-8th centuries in the lowlands, spreading to the upland fringes of Exmoor around the I oth century. The emergence of convertible husbandry at this time could also suggest that the South-West's equally distinctive historic landscape had also come into being at that date. There is no other evidence within the pollen sequences for a discontinuity in landscape exploitation between the first appearance of significant amounts of cereal pollen in the 7 th-8th centuries and the I $4^{\text {th }}$ century (when convertible husbandry is first recorded) that could account for the abandonment of the late prehistoric/Romano-British/post-Roman pattern of small enclosed farmsteads and its replacement with the historic landscape of today.

What is less clear is why this important change in landscape management occurred. A wide range of explanations has been suggested for the change to open-field agriculture in the Midlands. These can be summarised as follows:

- that a heavy mouldboard plough pulled by eight oxen required communal organisation of resources and large fields with long, narrow plough-units within which to manoeuvre; ${ }^{71}$

- that open fields provided a more equal share of a township's resources, ${ }^{72}$

- that open fields were introduced by Early Anglo-Saxon immigrants and resulted from the disintegration of landholding through partible inheritance $;^{73}$

- that open fields were created as a result of increasing pressure on resources, due to rising population, leading to greater co-operation $;{ }^{74}$

- that the reorganisation of the landscape occurred in the context of the fragmentation of large 'multiple estates'; 75 and

- that increasing demands from the Crown for taxation and military service, in the context of an expanding economy, provided the incentive and the

${ }^{71}$ E.g. F. Seebohm, The English Village Community (London, I890), 1 20-2; C. S. Orwin and C. S. Orwin, The Open Fields (Oxford, 1938), 37-44.

${ }_{72}$ E.g. P. Vinogradoff, Villeinage in England (Oxford, i 892), 236; G. G. Homans, English Villagers of the Thirteenth Century (Cambridge, I94 I), 90-I.

${ }_{73}^{73}$ E.g. H. L. Gray, English Field Systems (Cambridge, I I I 5), 4 I 5; Vinogradoff, op. cit. note 72, I 62.

${ }^{74}$ Thirsk I 964 and I966, op. cit. in note 3; R. Dodgshon, The Origin of British Field Systems: An Interpretation (London, I 980); Fox, op. cit. in note 50, I 2 I-32; D. Hall, 'The origins of open-field agriculture: the archaeological fieldwork evidence', 22-38 in T. Rowley (ed.), The Origins of Open Field Agriculture (London, I 98 r); Lewis et al., op. cit. in note 3 , I 99 .

${ }^{75}$ Fox, op. cit. in note 50, I oo; R. Faith, The English Peasantry and Growth of Lordship (Leicester, I 997), I 53-200. 
opportunity to increase productivity and the creation of a tradable surplus. ${ }^{76}$

Underlying this debate is also the issue of whether the restructuring of the landscape occurred as a grassroots response by the community or through landowners imposing their will. ${ }^{77}$

In the South-West there were indeed areas with small hamlets and common fields, though many places show none of the tell-tale signs of this communal approach to landscape management. Around Middle North Combe, Rackenford Moor and Molland Common isolated farmsteads dominate the landscape, each set within a compact block of closes held in severalty. As convertible husbandry is documented in areas with both common-field farming and landscapes held in severalty, it would appear unlikely that those explanations for the emergence of open-field farming in the Midlands that rely on the benefits of a nucleated settlement pattern or communal use of resources can be applied to the emergence of convertible husbandry in the South-West. In the South-West it is impossible to say whether there was a population increase during the 7 th-8th centuries, though the old social order certainly appears to have been replaced at this time. They abandoned the coastal royal citadels such as Tintagel and High Peak, beach markets such as Bantham and Mothecombe, along with their exchange links with the Mediterranean, and reoccupied hilltop settlements such as Haldon Hill and Raddon. ${ }^{78}$ At approximately the same time Devon was incorporated into the kingdom of the West Saxons (the minster church at Exeter being founded by 690 and probably 670$).{ }^{79}$ There is no reason to invoke traditional migrationist views of the Anglo-Saxon conquest, but this may have led to new patterns of lordship that encouraged changes in how they managed the countryside, and perhaps a breakdown of territorial structures/ estates. The latter was certainly at an advanced stage by the 8th-9th centuries when charters record estates with an average hidage of I 3.5 hides, compared to the Ioth century when they were an average of 4 hides. ${ }^{80}$

The suggested date of the 7 th-8th centuries for this significant change in the South-West's landscape is broadly contemporary with when we believe that a landscape reorganisation in the Midlands took place, which led to the creation of a single nucleated village and regularly arranged set of open fields within each

${ }^{76}$ Hall, op. cit. in note 74, 37; Lewis et al., op. cit. in note 3, I99-200.

77 Cf. Thirsk ig64 and I 966, op. cit. in note 3; and B. M. S. Campbell, 'Commonfield origins - the regional dimension', i I 2-29 in Rowley (ed.), op. cit. in note 74. See also C. Dyer, 'Power and conflict in the medieval village', 27-32 in Hooke (ed.), op. cit. in note 65; P. D. A. Harvey, 'Initiative and authority in settlement change', 3 I $^{-4} 4$ in M. Aston, D. Austin and C. Dyer (eds.), The Rural Settlements of Medieval England (Oxford, I 989 ).

${ }_{78}$ C. D. Morris, C. E. Batey, K. Brady, R. Harry, P. G. Johnson and C. Thomas, 'Recent work at Tintagel', Medieval Archaeol., 43 (I 999), 206-I5; J. A. Nowakowski and C. Thomas, Grave News from Tintagel: An Account of a Second Season of Archaeological Excavation at Tintagel Churchyard, Cornwall, I992 (Truro, I992); S. M. H. Pollard, 'Neolithic and Dark Age settlements on High Peak, Sidmouth, Devon', Proc. Devon Archaeol. Soc., 23 (r966), 35-59; Griffith and Reed, op. cit. in note i i; W. Horner, 'Secrets of the sands', Devon Archaeol. Soc. Newesletter May 200I, I (200 I), 8-9; Turner, op. cit. in note r o. For Haldon Hill and Raddon see note I I.

${ }^{79}$ D. Hooke, 'Saxon conquest and settlement', 95-I04 in R. Kain and W. Ravenhill (eds.), Historical Atlas of South-West England (Exeter, I 999); M. Todd, The South West to A.D. Iooo (London, I987), 267-3 I o.

${ }^{80}$ H. P. R. Finberg, The Early Charters of Devon and Cornwall (Leicester, I 953); Hooke, op. cit. in note I 3. 
township. Fieldwalking in Northamptonshire has suggested that nucleation occurred sometime between the mid- 7 th and mid-gth centuries; the latest pottery recovered from fieldwalking on the scattered settlements that were swept away during this reorganisation is of 'Middle Anglo-Saxon'-type, ${ }^{81}$ while 'Late Anglo-Saxon' pottery is almost wholly found in nucleated villages. ${ }^{82}$ Brown and Foard have suggested this initial nucleation of settlement in the Middle Anglo-Saxon Period may have pre-dated the imposition of a regular open-field system over whole townships. This was perhaps associated with the replanning of some villages, for which they suggest a gth or I oth-century date; documentary evidence can only suggest that open fields existed in the Midlands by the ioth century. ${ }^{83}$

To date, an 'evolutionary model' has emerged whereby 'this adaptation [villages and open fields], once introduced and established, probably spread by emulation. The nucleated settlements and regular open fields in so many communities across the East Midlands show so many similarities as to suggest that, as the success of the nucleated open-field village became evident, the idea spread following a standard model'. ${ }^{84}$ This idea that the concepts of settlement nucleation and the reorganisation of agricultural land into open fields spread out from the Midlands reinforces the impression that landscapes beyond the 'Central Province' simply failed to follow this lead. Lewis, Mitchell-Fox and Dyer, for example, suggest that in other regions, however, this adaptive evolution of fields, boundaries and settlements was not followed. Where the arable contribution to the economy was less dominant, the pressure on the land never reached the point at which a transformation of the landscape seemed either necessary or desirable. Although areas of continued dispersed settlement were subject to the same factors, such as increased population or the emergence of markets, nonetheless the availability of additional land for cultivation, their pastoral interests, or opportunities to make a living from the woods and wastes, insulated them from radical change' ${ }^{85}$

There is, however, a problem with this hypothesis. At the regional scale, such as the county of Somerset that straddles the 'Central' and 'Western' Provinces with nucleated and dispersed settlement patterns respectively, ${ }^{86}$ there is simply no correlation between high population and the decision by rural communities and/or their lords to restructure the landscape. The density

${ }^{81}$ T. Brown and G. Foard, 'The Saxon landscape: a regional perspective', 67-94 in P. Everson and T. Williamson (eds.), The Archaeology of Landscape (Manchester, I 998); G. Foard, 'Systematic fieldwalking and the investigation of Saxon settlement in Northants', World Archaeol., 9(iii) (I 978), 357-74; D. Hall and P. W. Martin, 'Brixworth, Northamptonshire: an intensive field survey', f. British Archaeol. Ass., I 32 ( r 979), I-6; D. Hall 'The Late Saxon countryside: villages and their fields', 99-1 22 in D. Hooke (ed.) Anglo-Saxon Settlements (Oxford, r 988); M. Shaw, 'The discovery of Saxon sites below fieldwalking scatters: settlement evidence at Brixworth and Upton', Northamptonshire Archaeol., 25 (1993/4), 77-92.

${ }^{82}$ In Leicestershire 90\% of 'Late Anglo-Saxon' findspots are from villages, while in Northamptonshire and Buckinghamshire the figure is about $80 \%$ : Lewis et al., op. cit. in note $3,8 \mathrm{I}$.

${ }_{83}$ Brown and Foard, op. cit. in note 81; M. Costen, The Origins of Somerset (Manchester, I 992), I 26; H. S. A. Fox, 'Approaches to the adoption of the Midland system', 64- I I I in Rowley (ed.), op. cit. in note 74; D. Hooke,

'Village development in the West Midlands', I 25-54 in Hooke (ed.), op. cit. in note 65.

${ }^{84}$ Lewis et al., op. cit. in note 3, 200. See also Robert and Wrathmell 2002, op. cit. in note 2 fig. 5. I I.

${ }^{85}$ Lewis et al., op. cit. in note 3, 200.

${ }^{86}$ Rippon 2004, op. cit. in note 7. 
of Domesday population in the hinterland of Exeter in central Devon with its typical South-Western landscape of dispersed settlement, for example, was the same or even higher than those parts of central and south-eastern Somerset that had a classic 'Midland' style landscape of villages and open fields (Fig. 3). ${ }^{87}$ The spread of villages and open fields down from the Midlands to central Somerset, which may have occurred around the i oth century, may well have followed the emulation model outlined above, with Glastonbury Abbey possibly being the lead proponent. ${ }^{88}$ In the meantime, however, the South-West landscape had already started to develop along its own trajectory with the extensive system of convertible husbandry supporting a density of population and plough-teams comparable to that of the Midlands. In fact, there may be other examples of a regionally distinctive phase of landscape evolution at this time. Fieldwalking in East Anglia, for example, has shown that around the 7 th-8th centuries the previously dispersed settlement pattern was also undergoing a process of nucleation around what is now the parish church, though by the period during which 'Late Anglo-Saxon' pottery was in use, secondary settlement foci started to emerge beside large commons. ${ }^{89}$ East Anglia also saw the development of open-field systems that were of a less regular character than in the Midlands. This region demonstrates yet another different trajectory of landscape change in the late Ist millennium A.D. Rather than the Midlands seeing a process of settlement nucleation that never quite 'reached the periphery', each of these regions was seeing periods of marked landscape change around the 7 th -8 th centuries. They may never have created villages in these regions because each was developing its own very successful approach to landscape management.

\section{GONGLUSION}

The full potential of palaeoenvironmental research for the past two millennia is yet to be realised because of difficulties in locating suitable sites for sampling. A crucial feature of the work presented here is that the pollen sequences have been obtained from small valley mires either embedded within, or very close to the margins of, those parts of the landscape that were settled throughout the late prehistoric, Romano-British and historic periods. The story told by these non-traditional pollen sites shows that the upland blanket bogs that have been a mainstay in previous palaeoenvironmental research are clearly not reflective of

${ }^{87}$ Cf. Darby, op. cit. in note I 3, figs. 84-6; and Roberts and Wrathmell 2000, op. cit. in note 2, figs. Io and I 7 . See also Williamson, op. cit. in note $3,28-35$.

${ }^{88}$ M. Aston and C. Gerrard, "Unique, traditional and charming": the Shapwick Project, Somerset', Antiq. F., 79 ( 1 999), I-58; N. Corcos, The Affinities and Antecedents of Medieval Settlement: Topographical Perspectives from Three of the Somerset Hundreds (Oxford, 2002), I 82-90; Rippon 2004, op. cit. in note 7 .

${ }^{89}$ A. Davison, The Evolution of Settlement in Three Norfolk Parishes (East Anglian Archaeol. 49, Dereham, I 990); A. J. Lawson, The Archaeology of Witton, near North Walsham, Norfolk (East Anglian Archaeol. i8, Dereham, I 987); J. Newman, 'The Late Roman and Anglo-Saxon settlement pattern in the Sandlings of Suffolk', 25-5 I in M. Carver (ed.), The Age of Sutton Hoo (Woodbridge, I 992); P. Wade-Martins, Fieldwork and Excavation on Village Sites in Launditch Hundred, Norfolk (East Anglian Archaeol. I o, Dereham, I 980); S. E. West and A. McLaughlin, Towards a Landscape History of Walsham le Willows (East Anglian Archaeol. 85, Dereham, I998); T. Williamson, 'Settlement Chronology and Regional Landscapes: The Evidence from the Claylands of East Anglia and Essex', I $53^{-75}$ in Hooke (ed.), op. cit. in note 8r; Williamson, op. cit. in note 3, 97-9. 
landscape history in the surrounding lowlands. The post-Roman woodland and heathland regeneration seen at The Chains, Codsend Moor and Hoar Moor (on the high uplands of Exmoor), for example, are entirely absent from the lowlands around Rackenford and even the upland fringes around Molland Common where there was almost complete continuity in how the landscape was being exploited at this time. The relatively high levels of cereal pollen seen from the

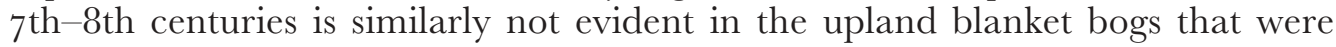
too far away from the cultivated areas to pick up the cereal pollen.

Against a backdrop of remarkable continuity in landscape management from the Late Iron Age through to the Post-Roman Period, this dramatic increase in cereals without an equivalent decline in pasture or woodland is taken to represent the pollen signature of what by the Late Middle Ages is documented as the regionally distinctive system of agriculture known as convertible husbandry. As there is no significant difference between the first appearance of such high levels of cereal pollen in the 7 th-8th centuries and the I $4^{\text {th }}$ century, when convertible husbandry is known to have been the norm, it is argued that the late prehistoric to post-Roman landscape was also probably replaced at this time by the historic landscape of today. There is no other palaeoenvironmental context for such a significant change in the landscape exploitation. The period from c. 680 to 830 has previously been described as the 'long eighth century', when England saw profound changes in settlement structure, architecture, the organisation of landed production and regional exchange, ${ }^{90}$ to which the agricultural changes seen in the South-West can now be added. It has often been assumed that the 'Midland' approach to managing the countryside, based around nucleated villages and open fields, never reached the South-West because that region was insulated from radical change due to its essentially pastoral economy and low population. But it now appears that the region had in fact developed its own very successful, regionally distinctive approach to landscape management that included a significant amount of arable cultivation and which stopped village creation spreading out from England's 'Central Province'.

\section{AGKNOWLEDGEMENTS}

This research was funded by The Leverhulme Trust (grant no. F/oor44/D). The authors are grateful to Jackie Hatton for completing the pollen analysis on the Parracombe sites, and Will Fletcher for contributing to field survey around Rackenford. The authors would also like to thank Harold Fox for discussing convertible husbandry and the history of Devon agriculture in general, along with commenting on an earlier draft of this paper, and the anonymous referee for his or her very constructive suggestions. All views expressed are, however, those of the authors. 